\title{
C-IFS-CB05-BASCOE: stratospheric chemistry in the Integrated Forecasting System of ECMWF
}

\author{
Vincent Huijnen $^{1}$, Johannes Flemming ${ }^{2}$, Simon Chabrillat ${ }^{3}$, Quentin Errera ${ }^{3}$, Yves Christophe ${ }^{3}$, \\ Anne-Marlene Blechschmidt ${ }^{4}$, Andreas Richter ${ }^{4}$, and Henk Eskes ${ }^{1}$ \\ ${ }^{1}$ Royal Netherlands Meteorological Institute, De Bilt, the Netherlands \\ ${ }^{2}$ European Centre for Medium-Range Weather Forecasts, Reading, UK \\ ${ }^{3}$ Belgian Institute for Space Aeronomy (BIRA-IASB), Brussels, Belgium \\ ${ }^{4}$ Institute of Environmental Physics, University of Bremen, Bremen, Germany \\ Correspondence to: Vincent Huijnen (huijnen@knmi.nl)
}

Received: 17 February 2016 - Published in Geosci. Model Dev. Discuss.: 7 March 2016

Revised: 8 July 2016 - Accepted: 18 August 2016 - Published: 6 September 2016

\begin{abstract}
We present a model description and benchmark evaluation of an extension of the tropospheric chemistry module in the Integrated Forecasting System (IFS) of the European Centre for Medium-Range Weather Forecasts (ECMWF) with stratospheric chemistry, referred to as CIFS-CB05-BASCOE (for brevity here referred to as C-IFSTS). The stratospheric chemistry originates from the one used in the Belgian Assimilation System for Chemical ObsErvations (BASCOE), and is here combined with the modified CB05 chemistry module for the troposphere as currently used operationally in the Copernicus Atmosphere Monitoring Service (CAMS). In our approach either the tropospheric or stratospheric chemistry module is applied, depending on the altitude of each individual grid box with respect to the tropopause. An evaluation of a 2.5-year long C-IFS-TS simulation with respect to various satellite retrieval products and in situ observations indicates good performance of the system in terms of stratospheric ozone, and a general improvement in terms of stratospheric composition compared to the C-IFS predecessor model version. Possible issues with transport processes in the stratosphere are identified. This marks a key step towards a chemistry module within IFS that encompasses both tropospheric and stratospheric composition, and could expand the CAMS analysis and forecast capabilities in the near future.
\end{abstract}

\section{Introduction}

Existing Earth observation systems in combination with global circulation models (GCMs) help to provide a better understanding of the Earth's atmospheric composition and changes therein (Hollingsworth et al., 2008). For the troposphere, hemispheric transport and chemical conversion of atmospheric composition influence regional air quality (Pausata et al., 2012; Im et al., 2015; Marécal et al., 2015). Also, the amount of stratospheric ozone directly impacts the forecast capabilities of surface solar irradiance $(\mathrm{Qu}$ et al., 2014), stressing the relevance of good stratospheric ozone forecasts. Stratospheric ozone further affects the chemical composition in the troposphere because of stratosphere-troposphere transport of ozone (Stevenson et al., 2006; Gaudel et al., 2015) and its radiative properties influencing the tropospheric photolysis rates. Beyond such direct implications for the troposphere, a comprehensive description of stratospheric composition allows a more complete understanding of processes taking place in the stratosphere, ranging from tracking the ozone hole (Lefever et al., 2015) and understanding the concentrations of ozone depleting substances (Chipperfield et al., 2015) to the assessment of dynamical effects such as the Quasi-Biennial Oscillation (QBO, Baldwin et al., 2001), and from implications of sudden stratospheric warmings on circulation patterns (Manney et al., 2015) to general radiative feedbacks of ozone, water vapour and $\mathrm{CO}_{2}$ on weather and climate (Solomon et al., 2010). 
These aspects have long been studied in the framework of chemistry transport models (CTMs) and, more recently, in GCMs; see e.g. the SPARC Chemistry-Climate Model Validation Activity (SPARC CCMVal, 2010). In GCMs the impact of stratospheric ozone chemistry on the tropospheric climate can explicitly be studied (e.g. Scaife et al., 2012), but meteorological models can also benefit from having a good representation of the stratospheric composition and its variability, considering the radiative effects and the resulting impact on stratospheric as well as tropospheric temperatures (Monge-Sanz et al., 2013). This becomes relevant for tropospheric forecast skills on long-range to seasonal timescales (Maycock et al., 2011).

Within a series of MACC (Monitoring Atmospheric Composition and Climate) European research projects a global forecast and assimilation system has been built, which is the core of the global system of the Copernicus Atmosphere Monitoring Service (CAMS, http://atmosphere.copernicus. eu). In CAMS, forecasts of atmospheric composition are carried out (Flemming et al., 2015; Morcrette et al., 2009; Engelen et al. 2009), which benefit from assimilation of satellite retrievals (Inness et al., 2015; Benedetti et al., 2009), to improve the initial conditions for composition fields in terms of reactive gases, aerosols and greenhouse gases. Here a tropospheric chemistry scheme has been embedded in ECMWF's Integrated Forecast System, referred to as Composition-IFS (C-IFS, Flemming et al., 2015). Even though the current operational version of C-IFS based on the Carbon Bond chemistry scheme (CB05) provides good model capability on tropospheric composition (Eskes et al., 2015), the stratosphere is only realistically constrained in terms of ozone. This is because so far the model ozone is based on a linear scheme (Cariolle and Tyssèdre, 2007) which is suitable owing to the data-assimilation capabilities of C-IFS of both total column and profile satellite retrievals (Flemming et al., 2011; Inness et al., 2015; Lefever et al., 2015).

Also, it is recognized that the applicability of radiation feedbacks of trace gases, such as ozone and water vapour, as produced through $\mathrm{CH}_{4}$ oxidation, is hampered by schemes that are based on linearizations (Cariolle and Morcrette, 2006; de Grandpré et al., 2009). This is due to the intrinsic dependencies on climatologies which are used to construct such schemes, and hence they may behave poorly in anomalous situations. Having full stratospheric chemistry available in the IFS therefore would not only allow one to study a wider range of atmospheric composition processes, but also have a more independent assessment of radiation feedbacks on temperature, hence providing the potential for improvements in stratospheric and tropospheric meteorology. These considerations drive the need for extension of C-IFS with a module for stratospheric chemistry. For this we use the chemistry scheme from the Belgian Assimilation System for Chemical ObsErvations (BASCOE) (Errera et al., 2008), which was developed to assimilate satellite observations of stratospheric composition.
BASCOE is based on a CTM of the stratosphere which is used to investigate stratospheric photochemistry (Theys et al., 2009; Muncaster et al., 2012). The assimilation system uses the 4D-VAR algorithm (Talagrand and Courtier, 1987) to produce reanalyses of stratospheric composition (Viscardy et al., 2010) which compare favourably with similar systems (Geer et al., 2006; Thornton et al., 2009) and facilitate detailed studies of transport processes in the stratosphere (Lahoz et al., 2011). The photochemistry module from the BASCOE CTM was implemented in the Canadian assimilation system GEM, demonstrating the potential of a coupled chemical-dynamical assimilation system for stratospheric studies (de Grandpré et al., 2009; Robichaud et al., 2010). BASCOE has been used and evaluated within the framework of MACC as an independent system for the provision of near real-time analyses of stratospheric ozone and for the validation of the corresponding product by the main assimilation system (Lefever et al., 2015; Eskes et al., 2015).

The CB05 tropospheric scheme has been combined with the stratospheric scheme from the BASCOE CTM to form a single chemistry mechanism that encompasses tropospheric and stratospheric chemistry throughout the atmosphere, here referred to as C-IFS-Atmos. However, this approach appears computationally expensive, due to the extended chemical mechanism. Therefore we have developed an approach for an optimized merging of the CB05 tropospheric chemistry scheme and the stratospheric chemistry scheme used in BASCOE within C-IFS. An assessment of the two chemistry schemes showed that there is only partial overlap in trace gases and reactions that are essential in both regimes. For instance, 15 out of the full list of 99 trace gases need to be treated in the chemical mechanisms for both troposphere and stratosphere. Also, the modelling of the photolysis rates and heterogeneous reactions has been optimized for application in troposphere and stratosphere separately. In this optimized approach we developed a flexible set-up where - within a single framework - either the tropospheric or stratospheric chemistry modules are addressed, referred to as C-IFS-TS. In this approach the parameterizations for the chemistry, including the respective chemistry mechanisms as optimized for troposphere and stratosphere separately, are retained.

In this paper we describe two merging approaches and provide benchmark evaluations of the C-IFS-Atmos and C-IFSTS systems with focus on the stratospheric composition. The ancestor BASCOE-CTM is also included in the comparison through a forward model run (without chemical data assimilation), in order to provide insight into the differences caused by the treatment of transport between C-IFS and BASCOE. The paper is organized as follows: in Sect. 2 the chemistry modules for the stratosphere are described and the merging with the tropospheric scheme is explained. Section 3 provides details on the set-up of the model runs and the observational data used for the model evaluation. Section 4 provides a basic model evaluation of the system. We finalize this paper with conclusions and an outlook for further work. 
Table 1. Trace gases relevant for the stratosphere which are constrained at the surface. The constant surface volume mixing ratios are also given.

\begin{tabular}{lllllll}
\hline $\mathrm{N}_{2} \mathrm{O}$ & $\mathrm{CFC11}$ & $\mathrm{CFC} 12$ & $\mathrm{CFC113}$ & $\mathrm{CFC114}$ & $\mathrm{CCl}_{4}$ & $\mathrm{CH}_{3} \mathrm{CCl}_{3}$ \\
\hline $3.22 \times 10^{-7}$ & $2.59 \times 10^{-10}$ & $5.37 \times 10^{-10}$ & $7.93 \times 10^{-11}$ & $4.25 \times 10^{-12}$ & $1.02 \times 10^{-10}$ & $4.53 \times 10^{-11}$ \\
\hline $\mathrm{HCFC} 22$ & $\mathrm{HA} 1301$ & $\mathrm{HA1211}$ & $\mathrm{CH}_{3} \mathrm{Br}$ & $\mathrm{CHBR}_{3}$ & $\mathrm{CH}_{3} \mathrm{Cl}$ & $\mathrm{CO}_{2}$ \\
\hline $1.70 \times 10^{-10}$ & $3.30 \times 10^{-12}$ & $4.62 \times 10^{-12}$ & $9.08 \times 10^{-12}$ & $1.17 \times 10^{-12}$ & $5.44 \times 10^{-10}$ & $3.80 \times 10^{-4}$ \\
\hline
\end{tabular}

\section{Atmospheric chemistry in C-IFS}

For general aspects related to chemistry modelling in C-IFS the reader is referred to Flemming et al. (2015). The meteorological model in the current version of C-IFS is based on IFS cycle 41r1 (ECMWF, 2015). The advection is simulated with a three-dimensional semi-Lagrangian advection scheme, which applies a quasi-monotonic cubic interpolation of the departure values.

In the following two subsections we describe the C-IFS modules for the stratospheric (BASCOE-based) and tropospheric (CB05-based) chemistry parameterizations, continued by a section describing the merging procedure of these two modules to form the C-IFS-TS system. The full list of trace gases is given in Table A1 in Appendix A, including the domains where they are actively treated within the chemistry.

\subsection{Stratospheric chemistry}

From the BASCOE system (Errera et al., 2008) the chemical scheme and the parameterization for polar stratospheric clouds (PSCs) has been implemented in C-IFS. The BASCOE chemical scheme used here is labelled "sb14a". It includes 58 species interacting through 142 gas-phase, 9 heterogeneous and 52 photolytic reactions. This chemical scheme merges the reaction lists developed by Errera and Fonteyn (2001) to produce short-term analyses, with the list included in the SOCRATES two-dimensional model for long-term studies of the middle atmosphere (Brasseur et al., 2000; Chabrillat and Fonteyn, 2003). The resulting list of species (see Table A1) includes all the ozone-depleting substances and greenhouse gases necessary for multi-decadal simulations of the couplings between dynamics and chemistry in the stratosphere, as well as the reservoir and shortlived species necessary for a complete description of stratospheric ozone photochemistry.

Gas-phase and heterogeneous reaction rates are taken from JPL evaluation 17 (Sander et al., 2011) and JPL evaluation 13 (Sander et al., 2000), respectively. Look-up tables of photolysis rates were computed offline by the TUV package (Madronich and Flocke, 1999) as a function of logpressure altitude, ozone overhead column and solar zenith angle. The photolysis tables used in chemical scheme sb14a are based on absorption cross sections from JPL evaluation
15 (Sander et al., 2006). The kinetic rates for heterogeneous chemistry are determined by the parameterization of Fonteyn and Larsen (1996), using classical expressions for the uptake coefficients on sulfate aerosols (Hanson and Ravishankara, 1994) and on PSCs (Sander et al., 2000).

The surface area density of stratospheric aerosols uses an aerosol number density climatology based on SAGE-II observations (Hitchman et al., 1994). Ice PSCs are presumed to exist at any grid point in the winter/spring polar regions where water vapour partial pressure exceeds the vapour pressure of water ice (Murphy and Koop, 2005).

Nitric acid tri-hydrate (NAT) PSCs are assumed when the nitric acid $\left(\mathrm{HNO}_{3}\right)$ partial pressure exceeds the vapour pressure of condensed $\mathrm{HNO}_{3}$ at the surface of NAT PSC particles (Hanson and Mauersberger, 1988). The surface area density is set to $2 \times 10^{-6} \mathrm{~cm}^{2} \mathrm{~cm}^{-3}$ for ice PSCs and $2 \times$ $10^{-7} \mathrm{~cm}^{2} \mathrm{~cm}^{-3}$ for NAT PSCs. The sedimentation of PSC particles causes denitrification and dehydration. This process is approximated by an exponential decay of $\mathrm{HNO}_{3}$ with a characteristic timescale of 20 days for grid points where NAT particles are supposed to exist, and an exponential decay of $\mathrm{HNO}_{3}$ and $\mathrm{H}_{2} \mathrm{O}$ with a characteristic timescale of 9 days for grid points where ice particles are supposed to exist.

Mass mixing ratios for $\mathrm{N}_{2} \mathrm{O}, \mathrm{CO}_{2}$ and a selection of anthropogenic and organic halogenic trace gases are constrained at the surface by a global mean constant value (Table 1). Assuming that trace gases are well mixed in the troposphere, this essentially serves as lower boundary conditions for the stratospheric chemistry.

\subsection{Tropospheric chemistry}

The tropospheric chemistry in the C-IFS is based on the CB05 mechanism (Yarwood et al., 2005). It adopts a lumping approach for organic species by defining a separate tracer species for specific types of functional groups. The scheme has been modified and extended to include an explicit treatment of $\mathrm{C} 1$ to $\mathrm{C} 3$ species as described in Williams et al. (2013), and $\mathrm{SO}_{2}$, di-methyl sulfide (DMS), methyl sulfonic acid (MSA) and ammonia (NH3) (Huijnen et al., 2010). A coupling to the MACC aerosol model is available (Huijnen et al., 2014), but is not switched on for this study. The reaction rates follow the recommendations given in either Sander et al. (2011) or Atkinson et al. (2006). The modified band ap- 
Table 2. Number of trace gases, the chemistry scheme in the troposphere and stratosphere, and the corresponding number of reactions (gas-phase, heterogeneous and photolytic), as well as specification of the circulation model and computational expenses of a 1-month run on T255L60 in terms of system billing units (SBU) for various C-IFS model versions. For completeness the BASCOE-CTM system is also indicated.

\begin{tabular}{llllll}
\hline & C-IFS-T & C-IFS-S & C-IFS-Atmos & C-IFS-TS & BASCOE-CTM \\
\hline No. of trace gases & 55 & 59 & 99 & 99 & 59 \\
\hline $\begin{array}{l}\text { Chemistry scheme } \\
\text { in troposphere }\end{array}$ & CB05 & $\begin{array}{l}\text { BASCOE } \\
(P<400 \mathrm{hPa})\end{array}$ & CB05+ BASCOE & CB05 & $\begin{array}{l}\text { BASCOE } \\
(P<400 \mathrm{hPa})\end{array}$ \\
\hline $\begin{array}{l}\text { Chemistry scheme } \\
\text { in stratosphere }\end{array}$ & CB05/Cariolle & BASCOE & CB05+ BASCOE & BASCOE & BASCOE \\
\hline $\begin{array}{l}\text { No. of reactions } \\
\text { (gas/het/photo) }\end{array}$ & $93 / 3 / 18$ & $142 / 9 / 52$ & $211 / 11 / 60$ & $93 / 3 / 18$ or & $142 / 9 / 52$ \\
\hline $\begin{array}{l}\text { Circulation model } \\
\text { GBU }\end{array}$ & GCM & GCM & GCM & GCM & CTM \\
\hline $\begin{array}{l}\text { * BASCOE does not run on the ECMWF supercomputing facility and hence cannot be compared directly to C-IFS in terms of computational } \\
\text { resources. }\end{array}$ & & & &
\end{tabular}

proach (MBA), which is adopted for the computation of photolysis rates (Williams et al., 2012), uses seven absorption bands across the spectral range $202-695 \mathrm{~nm}$. At instances of large solar zenith angles $\left(71-85^{\circ}\right)$ a different set of band intervals is used. In the MBA the radiative transfer calculation using the absorption and scattering components introduced by gases, aerosols and clouds is computed online for each of the predefined band intervals. The complete chemical mechanism as applied for the troposphere is extensively documented in Flemming et al. (2015). There a specification of the emissions and deposition of tropospheric reactive trace gases is provided as well.

\subsection{Merging procedures for the tropospheric and stratospheric chemistry}

Here we investigate two options to merge tropospheric and stratospheric chemistry, as also summarized in Table 2 . The chemistry mechanism for C-IFS-Atmos is composed by simply combining the reaction mechanisms for troposphere and stratosphere into one large mechanism, removing reactions that are duplicated. In contrast to this model version, here we propose an approach for a more efficient merging of the chemistry modules for the troposphere and stratosphere to form the C-IFS-TS system. Key chemical cycles differ between troposphere and stratosphere, hence allowing different chemical mechanisms. For example, the oxidation of nonmethane hydrocarbons (NMHCs) is essentially taking place in the troposphere and represents an important driver for tropospheric $\mathrm{O}_{3}$ production. The chemical evolution of PAN and organic nitrate can be neglected in the stratosphere. On the other hand, $\mathrm{N}_{2} \mathrm{O}$ and CFCs are essentially chemically inactive in the troposphere and will only be photolysed by UV radiation in the stratosphere. Therefore, the chemical reac- tions involving these gases do not need to be accounted for in the troposphere. Also, the parameterization of the photolysis rates leads to different requirements for the troposphere and stratosphere, as will be discussed in the next subsection. Finally, the numerical solver of the chemical mechanism contributes substantially to the total costs of the model run in terms of run-time, depending on the size of the reaction mechanism. These elements have motivated us to divide the chemistry in the C-IFS-TS system into a tropospheric part and a stratospheric part. Note that there is only one set of transported atmospheric trace gases, and only the position of the grid box above or below the tropopause determines whether the tropospheric or stratospheric chemistry is applied.

The tropopause can be defined based on different criteria. A common approach is to use a dynamical criterion such as the isentropic potential vorticity (e.g. Thuburn and Craig, 1997), but this fails in regions of small absolute vorticity, notably in the tropics. A definition based on the lapse rate (WMO, 1957) is an alternative, but may not be well defined in the presence of multiple stable layers. We therefore choose to base our criterion on the chemical composition of the atmosphere considering that the tropopause is associated with sharp gradients in trace gases (e.g. Gaudel et al., 2015). This has the advantage that parcels with tropospheric/stratospheric composition can be traced dynamically, and the most appropriate chemistry scheme can be adopted to it. In our simulation we use a chemical definition of the tropopause level, where tropospheric grid cells are defined at $\mathrm{O}_{3}<200 \mathrm{ppb}$ and $\mathrm{CO}>40 \mathrm{ppb}$, for $P>40 \mathrm{hPa}$. With this definition the associated tropopause pressure ranges in practice between approx. 270 and $80 \mathrm{hPa}$ for sub-tropics and tropics, respectively. 
Table 3. Parameterization of photolysis rates for the troposphere (CB05-based) and stratosphere (BASCOE-based).

\begin{tabular}{|c|c|c|}
\hline & $\begin{array}{l}\text { Troposphere } \\
\text { (Williams et al., 2012) }\end{array}$ & $\begin{array}{l}\text { Stratosphere } \\
\text { (Errera and Fonteyn, 2001) }\end{array}$ \\
\hline No. of $J$ rates & 18 & 52 \\
\hline Method & Two-stream online solver, $204<\lambda<705 \mathrm{~nm}$ & Look-up table approach, $116<\lambda<705 \mathrm{~nm}$ \\
\hline Dependencies & $\begin{array}{l}\mathrm{O}_{3} \text { overhead, pressure, solar zenith angle, } \\
\text { cloud, aerosol, surface albedo, temperature }\end{array}$ & $\mathrm{O}_{3}$ overhead, pressure, solar zenith angle \\
\hline Terminator treatment & $J>0$ for $\mathrm{sza}<85^{\circ}$ & $\begin{array}{l}J>0 \text { for sza }<96^{\circ} \\
\text { Chapman approximation }\end{array}$ \\
\hline
\end{tabular}

For both troposphere (CB05) and stratosphere (BASCOE) the numerical solver is generated using the Kinetic PreProcessor (KPP, Sandu and Sander, 2006) software. Specifically we adopt the standard four-stage, third-order Rosenbrock solver (Rodas3). This is different from the Eulerian backward implicit solver as used in Flemming et al. (2015), and is motivated by the improved coding flexibility and accuracy.

Most of the gas-phase reactions that take place both in the troposphere and stratosphere, such as $\mathrm{NO}_{x}$ and $\mathrm{HO}_{x}$ reactions, are simulated in identical ways in both chemistry schemes. It is worth mentioning that the constituents $\mathrm{O}^{1} \mathrm{D}$ and $\mathrm{O}^{3} \mathrm{P}$, produced from $\mathrm{O}_{3}$ and $\mathrm{O}_{2}$ photolysis, are not explicitly computed in the troposphere, as $\mathrm{O}^{1} \mathrm{D}$ and $\mathrm{O}^{3} \mathrm{P}$ are assumed to react with $\mathrm{O}_{2}, \mathrm{O}_{3}$ and $\mathrm{N}_{2}$ only. This is different for the stratosphere, where $\mathrm{O}^{1} \mathrm{D}$ and $\mathrm{O}^{3} \mathrm{P}$ are involved in many reactions. For trace gases whose chemistry is currently neglected in the stratosphere (the NMHCs, PAN, organic nitrate, $\mathrm{SO}_{2}$ ) we adopt a 10-day decay rate to prevent their spurious accumulation in the stratosphere. Hence these losses are currently not accounted for in the stratospheric chemical mechanisms and do not contribute either to the load of stratospheric aerosols. Note that tropospheric halogen chemistry, which contributes to near-surface ozone depletion in springtime polar regions and to changes in oxidative capacity in the tropical marine boundary layer (von Glasow and Crutzen, 2007), is currently neglected, even though related trace gases are available. By inspection of individual constituent fields we have ensured that the merging strategy does not result in spurious jumps at the interface between troposphere and stratosphere; see also Figs. S2-S5 in the Supplement. When the system is run with stratospheric chemistry only (C-IFSS), all chemistry and emissions are switched off at altitudes below $400 \mathrm{hPa}$ and constrained by surface boundary conditions.

The four options to run these types of C-IFS experiments and the computational costs are given in Table 2. As compared to the C-IFS-T experiments, the costs of running an experiment including full stratospheric chemistry with the CIFS-TS system have increased by $\sim 50 \%$. Most of this increase is caused by the computation of the chemistry and not the tracer transport due to the efficiency of the semi-
Lagrangian advection scheme for multiple tracers. The CIFS-Atmos set-up where tropospheric chemistry and stratospheric chemistry were merged into a single reaction mechanism led to an increase in costs by $\sim 50 \%$ compared to CIFS-TS, indicating the benefit of having separate solver codes for tropospheric and stratospheric chemistry. The C-IFS-TS implementation allows for an easy switch between system set-ups compared to the C-IFS-Atmos implementation. For completeness, specifications of the BASCOE-CTM are also provided in Table 2, which is identical in terms of stratospheric chemistry parameterization compared to C-IFS-TS and C-IFS-S. Clearly the essential difference compared to the C-IFS set-up refers to the fact that BASCOE is used here as a CTM, while C-IFS is a GCM. Most notably this implies a different advection treatment and a different horizontal grid (see Sect. 3).

\subsubsection{Merging photolysis rates}

For parameterization of the photolysis rates, the modified band approach (MBA, Williams et al., 2012) and the look-up table approach (Errera and Fonteyn, 2001) are retained (see Table 3), as these have been optimized in the past for applications in the troposphere and stratosphere, respectively. While for tropospheric conditions scattering and absorption properties of clouds and aerosol strongly impact the magnitude of photolysis rates and hence the local chemical composition, this is of less relevance in the stratosphere. Wavelengths shorter than $202 \mathrm{~nm}$, on the other hand, are largely blocked by stratospheric ozone and oxygen and do not contribute to radiation in the troposphere (Williams et al., 2012). At higher altitudes these short wavelengths contribute to the Chapman cycle and to the breakdown of $\mathrm{CH}_{4}, \mathrm{CFCs}$ and $\mathrm{N}_{2} \mathrm{O}$ either directly or through oxidation by $\mathrm{O}^{1} \mathrm{D}$. Also, the presence of sunlight at solar zenith angles (SZAs) larger than $90^{\circ}$ at high altitudes needs to be accounted for in the stratosphere due to the Earth's curvature. This plays a role in the timing of springtime ozone depletion in the polar lower stratosphere, but may be neglected in the troposphere.

Table 4 lists the photolysis rates that are active in both the troposphere and stratosphere. Photolysis rates for reactions occurring in both the troposphere and stratosphere are merged at the interface, in order to ensure a smooth transi- 
Table 4. Selection of photolytic reactions that are merged between the troposphere and stratosphere. The reaction product $\mathrm{O}_{2}$ is not shown.

\begin{tabular}{lll}
\hline Name & Reaction (stratosphere) & Reaction products (troposphere) \\
\hline$J_{\mathrm{O}_{3}}$ & $\mathrm{O}_{3}+h v \rightarrow \mathrm{O}^{1} \mathrm{D}$ & \\
$J_{\mathrm{NO}_{2}}$ & $\mathrm{NO}_{2}+h v \rightarrow \mathrm{NO}+\mathrm{O}$ & $\mathrm{NO}+\mathrm{O}_{3}$ \\
$J_{\mathrm{H}_{2} \mathrm{O}_{2}}$ & $\mathrm{H}_{2} \mathrm{O}_{2}+h v \rightarrow 2 \mathrm{OH}$ & \\
$J_{\mathrm{HNO}_{3}}$ & $\mathrm{HNO}_{3}+h v \rightarrow \mathrm{OH}+\mathrm{NO}_{2}$ & \\
$J_{\mathrm{HO}_{2} \mathrm{NO}_{2}}$ & $\mathrm{HO}_{2} \mathrm{NO}_{2}+h v \rightarrow \mathrm{HO}_{2}+\mathrm{NO}_{2}$ & \\
$J_{\mathrm{N}_{2} \mathrm{O}_{5}}$ & $\mathrm{~N}_{2} \mathrm{O}_{5}+h v \rightarrow \mathrm{NO}_{2}+\mathrm{NO}_{3}$ & \\
$J_{\mathrm{CH}_{2} \mathrm{O}}-a$ & $\mathrm{CH}_{2} \mathrm{O}+h v \rightarrow \mathrm{HCO}+\mathrm{H}$ & $\mathrm{CO}+2 \mathrm{HO}_{2}$ \\
$J_{\mathrm{CH}_{2} \mathrm{O}}-b$ & $\mathrm{CH}_{2} \mathrm{O}+h v \rightarrow \mathrm{CO}+\mathrm{H}_{2}$ & $\mathrm{CO}$ \\
$J_{\mathrm{NO}_{3}}-a$ & $\mathrm{NO}_{3}+h v \rightarrow \mathrm{NO}+\mathrm{O}$ & $\mathrm{NO} 2+\mathrm{O}_{3}$ \\
$J_{\mathrm{NO}_{3}}-b$ & $\mathrm{NO}_{3}+h v \rightarrow \mathrm{NO}$ & \\
$J_{\mathrm{O}_{2}}$ & $\mathrm{O}_{2}+h v \rightarrow 2 \mathrm{O}$ & \\
$J_{\mathrm{CH}_{3} \mathrm{OOH}}$ & $\mathrm{CH}_{3} \mathrm{OOH}+h v \rightarrow \mathrm{CH} \mathrm{O}+\mathrm{OH}$ & $\mathrm{CH}_{2} \mathrm{O}+\mathrm{HO}_{2}+\mathrm{OH}$ \\
\hline
\end{tabular}

* Only specified in case this is different from the stratospheric reaction.

tion between the two schemes. This is done by an interpolation at four model levels around the interface level between both parameterizations, for SZA $<85^{\circ}$. For larger SZAs the original value for the photolysis rate is retained in case of stratospheric chemistry, while it is switched off for the troposphere.

Note that even though the reaction rates have been merged, the products from the same photolytic reactions are sometimes different as a consequence of the different reaction mechanisms between the troposphere and stratosphere.

An example of the merging strategy is given in Fig. 1. It shows that at the interface for $J \mathrm{O}_{3}$ and $J \mathrm{NO}_{2}$, on average a small increase in the merged photolysis rate is seen towards lower altitudes, with the switch to MBA in the troposphere. Even though such jumps are undesirable, no visible impact on local chemical composition was found, for any of the trace gases involved in both tropospheric and stratospheric chemistry; see also Figs. S1-S3 in the Supplement. This can be explained by the sufficiently small difference in the photolysis rates at the merging altitude of the photolysis and chemistry schemes, combined with the sufficiently long lifetime of the affected trace gases.

\subsubsection{Tracer transport settings}

Tracer transport is treated identically for all individual chemical trace gases. Since the semi-Lagrangian advection does not formally conserve mass (Flemming and Huijnen, 2011; de Grandpré et al., 2016), a global mass fixer is applied (Diamantakis and Flemming, 2014) to all but a few constituents, including $\mathrm{NO}, \mathrm{NO}_{2}$ and $\mathrm{H}_{2} \mathrm{O}$. Rather than conserving mass during the advection step of the individual components NO and $\mathrm{NO}_{2}$, this is enforced to a stratospheric $\mathrm{NO}_{x}$ tracer defined as the sum of $\mathrm{NO}$ and $\mathrm{NO}_{2}$. While a chemical $\mathrm{H}_{2} \mathrm{O}$ trace gas is defined in the full atmosphere, in the troposphere $\mathrm{H}_{2} \mathrm{O}$ mass mixing ratios are constrained by the humidity $(q)$ simulated in the meteorological model in IFS and provide
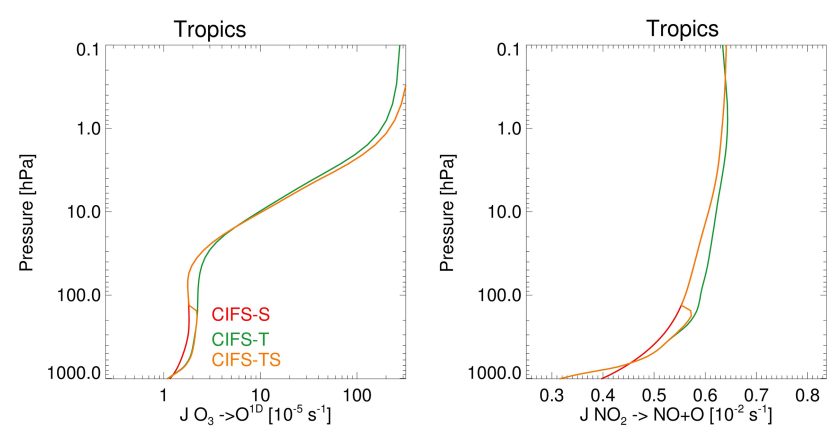

Figure 1. Illustration of the merging procedure for photolysis rates between the tropospheric and stratospheric parameterizations for the reactions $\mathrm{O}_{3} \rightarrow \mathrm{O}^{1} \mathrm{D}$ (left) and $\mathrm{NO}_{2} \rightarrow \mathrm{NO}+\mathrm{O}$ (right) as zonally averaged over the tropics for 1 April 2008.

a boundary condition for water vapour in the stratosphere. Stratospheric $\mathrm{H}_{2} \mathrm{O}$ (i.e. above the tropopause level) is governed by chemical production and loss. The global advection errors in $\mathrm{H}_{2} \mathrm{O}$ essentially originate from the tropospheric part because by far most $\mathrm{H}_{2} \mathrm{O}$ mass is located in the troposphere and the spatial gradients are much more pronounced. This should not affect the stratospheric $\mathrm{H}_{2} \mathrm{O}$ mass budget; therefore, the global mass fixer for the stratospheric $\mathrm{H}_{2} \mathrm{O}$ tracer has been switched off. This prevents spurious trends in stratospheric $\mathrm{H}_{2} \mathrm{O}$ columns over the years (not shown), indicating that $\mathrm{H}_{2} \mathrm{O}$ mass conservation is well ensured in the stratosphere.

\section{Model set-up and observations used}

We have executed runs with C-IFS-TS and C-IFS-Atmos for the period April 2008 until December 2010. Stratospheric ozone in C-IFS-TS is further compared to that of the C-IFS-T system (Flemming et al., 2015). This uses the ECMWF standard linear ozone scheme (version 2a, Cariolle and Teyssè- 
dre, 2007) in the stratosphere, while stratospheric $\mathrm{HNO}_{3}$ is constrained through a climatological ratio of $\mathrm{HNO}_{3} / \mathrm{O}_{3}$ at $10 \mathrm{hPa}$ (Flemming et al., 2015).

We have initialized all C-IFS runs on 1 April 2008 using assimilated concentration fields from the BASCOE system in the stratosphere for this date. The horizontal resolution of these runs is T255 (i.e. approx. $0.7^{\circ}$ long/lat) with $60 \mathrm{lev}$ els in the vertical. Meteorology in the C-IFS runs is relaxed towards ERA-Interim.

Intercomparison of runs C-IFS-TS and C-IFS-Atmos aims to provide a justification of our approach to split the chemistry into two regions, while intercomparison of C-IFS-TS with C-IFS-T can be used to identify the changes to stratospheric composition modelling between full stratospheric chemistry and the baseline approach with the linear ozone scheme.

The performance of the C-IFS runs has further been compared against the BASCOE-CTM (without chemical data assimilation), using the same chemical mechanism and parameterizations for photolysis and heterogeneous chemistry as implemented in the C-IFS-TS. This serves as a model reference for the C-IFS implementation of stratospheric chemistry. While C-IFS evaluates tracer transport on a reduced Gaussian grid, the BASCOE-CTM uses a regular latitudelongitude grid. It is run here with a resolution of $1.125^{\circ}$ long-lat similar to the resolution chosen for the C-IFS used, and on the same vertical grid of 60 levels. The BASCOECTM is driven by temperature, pressure and wind fields simulated by the C-IFS runs. However, while BASCOE adopts a flux-form advection scheme (Lin and Rood, 1996), the IFS uses the semi-Lagrangian scheme for advection, accounts for vertical diffusion and includes a parameterization for convection (ECMWF, 2015). Using essentially the same dynamical fields together with an identical implementation of the chemistry code should allow one to identify differences due to the different transport schemes between C-IFS and the BASCOE-CTM. Common chemical biases between both systems also point to issues in the chemical parameterizations such as reaction mechanism, photolysis, heterogeneous chemistry and sedimentation.

\subsection{Observational data used for validation}

We evaluate the C-IFS runs in terms of stratospheric $\mathrm{O}_{3}$, $\mathrm{NO}_{2}, \mathrm{~N}_{2} \mathrm{O}, \mathrm{CH}_{4}, \mathrm{H}_{2} \mathrm{O}$ and $\mathrm{HCl}$, and for this purpose use a range of observation-based products.

Model results are compared with retrievals (version 3) of $\mathrm{O}_{3}$ (Froidevaux et al., 2008a), $\mathrm{ClO}$ (Santee et al., 2008), $\mathrm{H}_{2} \mathrm{O}$ (Read et al., 2007) and $\mathrm{HCl}$ (Froidevaux et al., 2008b) from the Microwave Limb Sounder (MLS) onboard the Aura satellite and with retrievals (version 6) of $\mathrm{O}_{3}$ (Ceccherini et al., 2008), $\mathrm{HNO}_{3}$ (Wang et al., 2007) and $\mathrm{NO}_{2}$ (Wetzel et al., 2007) from limb emission spectra recorded by the Michelson Interferometer for Passive Atmospheric Sounding (MIPAS) onboard European satellite Envisat.
The MLS error budget is reported in Livesey et al. (2011). For $\mathrm{HCl}$ observations between 1 and $20 \mathrm{hPa}$ the precision and accuracy are below 10 and $15 \%$, respectively. Between 46 and $100 \mathrm{hPa}$, these are below 0.3 and $0.2 \mathrm{ppbv}$, respectively. For $\mathrm{H}_{2} \mathrm{O}$ between 0.46 and $100 \mathrm{hPa}$, precision and accuracy are below 15 and $8 \%$. MIPAS random and systematic errors for various trace gases are reported by Raspollini et al. (2013). For $\mathrm{NO}_{2}$ between 25 and $50 \mathrm{~km}$ altitude these are below 10 and $20 \%$, respectively. For $\mathrm{HNO}_{3}$ between 15 and $30 \mathrm{~km}$, these are below 8 and $15 \%$, while for $\mathrm{O}_{3}$ between 20 and $55 \mathrm{~km}$ these are below 5 and $10 \%$. At $15 \mathrm{~km}$, these errors increase to 10 and $20 \%$, respectively.

Total column $\mathrm{O}_{3}$ is validated against KNMI's multi-sensor reanalysis version 2 (MSR, van der A et al., 2015), which for the 2008-2010 time period is based on Solar Backscattering Ultraviolet radiometer (SBUV/2), Global Ozone Monitoring Experiment (GOME), SCanning Imaging Absorption spectroMeter for Atmospheric CartograpHY (SCIA$\mathrm{MACHY}$ ) and Ozone Monitoring Instrument (OMI) observations. The satellite retrieval products used in the MSR are bias-corrected with respect to Brewer and Dobson spectrophotometers to remove discrepancies between the different satellite data sets. The uncertainty in the product, as quantified by the bias of the observation-minus-analysis statistics, is in general less than $1 \mathrm{DU}$.

$\mathrm{O}_{3}$ profiles are compared to ozonesonde data that are acquired from the World Ozone and Ultaviolet radiation Data Centre (WOUDC). The precision of the ozonesondes is of the order of $5 \%$ in the stratosphere (Hassler et al., 2014), when based on electrochemical concentration cell (ECC) devices ( $\sim 85 \%$ of all soundings). Larger random errors $(5-10 \%)$ are found for other sonde types, and in the presence of steep gradients and where the ozone amount is low. Sondes at 19, 12, 2 and 1 individual stations are used for the evaluation over Northern Hemisphere mid-latitudes, tropics, Southern Hemisphere mid-latitudes and the Antarctic, respectively.

Stratospheric $\mathrm{NO}_{2}$ columns are compared to observational data from the SCIAMACHY (Bovensmann et al., 1999) UVVIS (ultraviolet-visible) and NIR (near-infrared) sensor onboard the Envisat satellite. The satellite retrievals are based on applying the differential optical absorption spectroscopy (DOAS) (Platt and Stutz, 2008) method to a $425-450 \mathrm{~nm}$ wavelength window. Stratospheric $\mathrm{NO}_{2}$ columns from SCIAMACHY presented here are in fact total columns derived by dividing retrieved slant columns of $\mathrm{NO}_{2}$ by a stratospheric air mass factor and contain data over the clean Pacific Ocean $\left(180-220^{\circ} \mathrm{E}\right)$ only (Richter et al., 2005). Although in this region the contribution of the troposphere to total column $\mathrm{NO}_{2}$ is small, stratospheric column $\mathrm{NO}_{2}$ from SCIAMACHY is still somewhat positively biased by a tropospheric contribution. However, stratospheric air mass factors for $\mathrm{NO}_{2}$ are usually large compared to tropospheric ones, so that the uncertainty resulting from this should only have a minor impact on the data analysis presented in this study. 
Monthly mean stratospheric $\mathrm{NO}_{2}$ columns are associated with relative uncertainties of roughly $5-10 \%$ and an additional absolute uncertainty of $1 \times 10^{14}$ molec $\mathrm{cm}^{-2}$. To account for differences in observation and model output time, simulations are interpolated linearly to the Equator-crossing time of SCIAMACHY (10:00 LT). In addition, only model data for which satellite observations exist are included in the corresponding comparisons.

Furthermore, satellite-based observations are used from the Atmospheric Chemistry Experiment - Fourier Transform Spectrometer (ACE-FTS) onboard Canadian satellite mission SCISAT-1 (first Science Satellite, Bernath et al., 2005). This is a high spectral resolution Fourier transform spectrometer operating with a Michelson interferometer. Vertical profiles of atmospheric volume mixing ratios of trace constituents are retrieved from the occultation spectra, as described in Boone et al. (2005), with a vertical resolution of $3-4 \mathrm{~km}$ at maximum. Here we use level 2 retrievals (version 3.0) of $\mathrm{N}_{2} \mathrm{O}$ and $\mathrm{CH}_{4}$.

ACE-FTS $\mathrm{N}_{2} \mathrm{O}$ observations between 6 and $30 \mathrm{~km}$ agree to within $15 \%$ of independent observations, while above they agree to within $\pm 4 \mathrm{ppbv}$ (Strong et al., 2008). The uncertainty in ACE-FTS $\mathrm{CH}_{4}$ observations is within $10 \%$ in the upper troposphere-lower stratosphere, and within $25 \%$ in the middle and higher stratosphere up to the lower mesosphere $(<60 \mathrm{~km})$ (De Mazière et al., 2008).

Three-hourly C-IFS and BASCOE-CTM output has been interpolated in space and time to match with any of these observations.

\section{Model evaluation}

Figure 2 shows the mean $\mathrm{O}_{3}$ partial columns (PCs) against observations from Aura MLS v3.0 over the poles and the tropics. In C-IFS-T, applying the Cariolle parameterization, the annual cycle over the Arctic is very well simulated, but a constant overestimation of $50 \mathrm{DU}(20 \%)$ is found. In the tropics the bias is much smaller, with a slight underestimation (10 DU, $5 \%$ ). In the Antarctic, the results are remarkably good during the ozone hole episodes, but there is a serious overestimation developing from February until the beginning of August, when it reaches $50 \mathrm{DU}(30 \%)$, i.e. as much as in the Arctic. CIFS-Atmos and CIFS-TS provide very similar results over the full time period, suggesting that our approach to keep two different solvers in each region is valid for stratospheric ozone. Also, after an initialization period of a few months, the model runs do not present any obvious drift, and the differences with BASCOE-CTM are very small. This implies that differences due to the model configuration regarding transport are not crucial for lower stratospheric ozone at these timescales. In the tropics the C-IFS-TS and C-IFS-Atmos results are slightly better than those with BASCOE-CTM, potentially due to the missing parameterization for convection. In the Antarctic, the parameterization

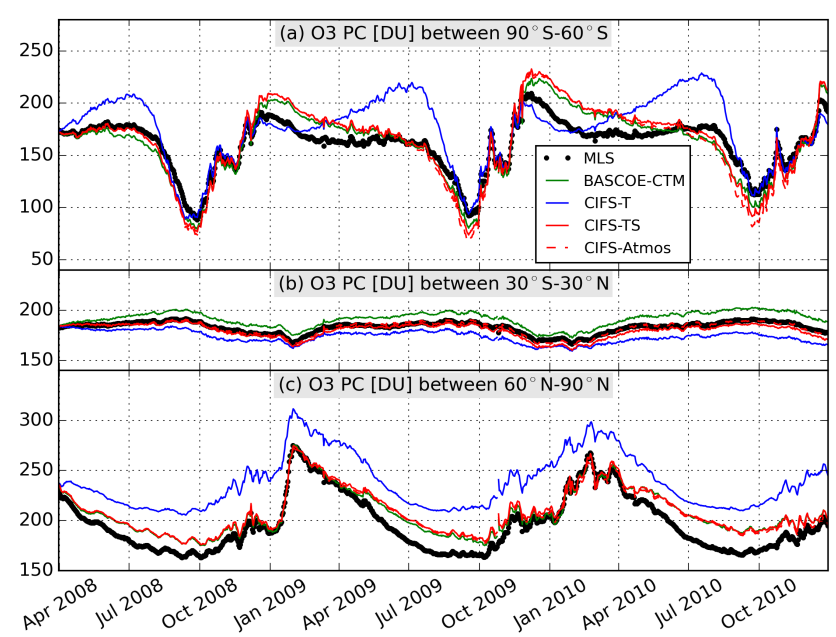

Figure 2. Daily averages of $\mathrm{O}_{3}$ partial columns $(10-100 \mathrm{hPa})$ for the Arctic $\left(60-90^{\circ} \mathrm{N}\right)$, tropics $\left(30^{\circ} \mathrm{S}-30^{\circ} \mathrm{N}\right)$ and Antarctic $(60-$ $90^{\circ} \mathrm{N}$ ) over the period April 2008-December 2010. Data sets are averaged in 5-day bins and model output is interpolated to the location and time of Aura MLS v3 retrievals (black dots). Blue line: CIFS-T; green line: BASCOE-CTM; red dashed line: C-IFS-Atmos; red solid line: C-IFS-TS.

of PSC leads to an overestimation of spring-time ozone depletion, while the Cariolle parameterization simulates very well the lowest columnar values observed in September, as discussed in more detail below. The recovery of ozone is overestimated by 20 DU (10\%) in December-January. While the amplitude of the annual cycle is overestimated above the Antarctic, its structure matches well with the observations.

An evaluation of $\mathrm{O}_{3}$ total columns (TCs) against the MSR at various latitude bands is given in Fig. S6 in the Supplement. Considering the missing tropospheric chemistry in the BASCOE-CTM, this system is not well constrained in terms of the $\mathrm{O}_{3} \mathrm{TC}$, which implies that it is not useful to include its results here. The TC comparison confirms the evaluation with PC from Aura MLS observations, showing a strong positive bias over the $\mathrm{NH}$ mid-latitudes and Arctic for $\mathrm{C}$ IFS-T, which is reduced for C-IFS-Atmos and C-IFS-TS. These model versions do not show a significant trend during the 2009-2010 period. For the tropical and Southern Hemisphere mid-latitudes, all C-IFS versions show a similar performance, with C-IFS-Atmos showing a small positive offset with respect to C-IFS-TS of approx. 2-8 DU, depending on the latitude band and season.

Closer inspection of $\mathrm{O}_{3}$ profiles against sondes averaged over the $\mathrm{NH}$ mid-latitudes, tropics and $\mathrm{SH}$ mid-latitudes for the DJF and JJA seasons in 2009 and 2010 (Figs. 3 and 4) shows biases in a generally similar order of magnitude, although frequently with opposite sign, for C-IFS-TS and CIFS-Atmos compared to C-IFS-T. Especially over the extratropics the C-IFS-TS and C-IFS-Atmos model versions show lower mixing ratios than C-IFS-T at the middle stratosphere 

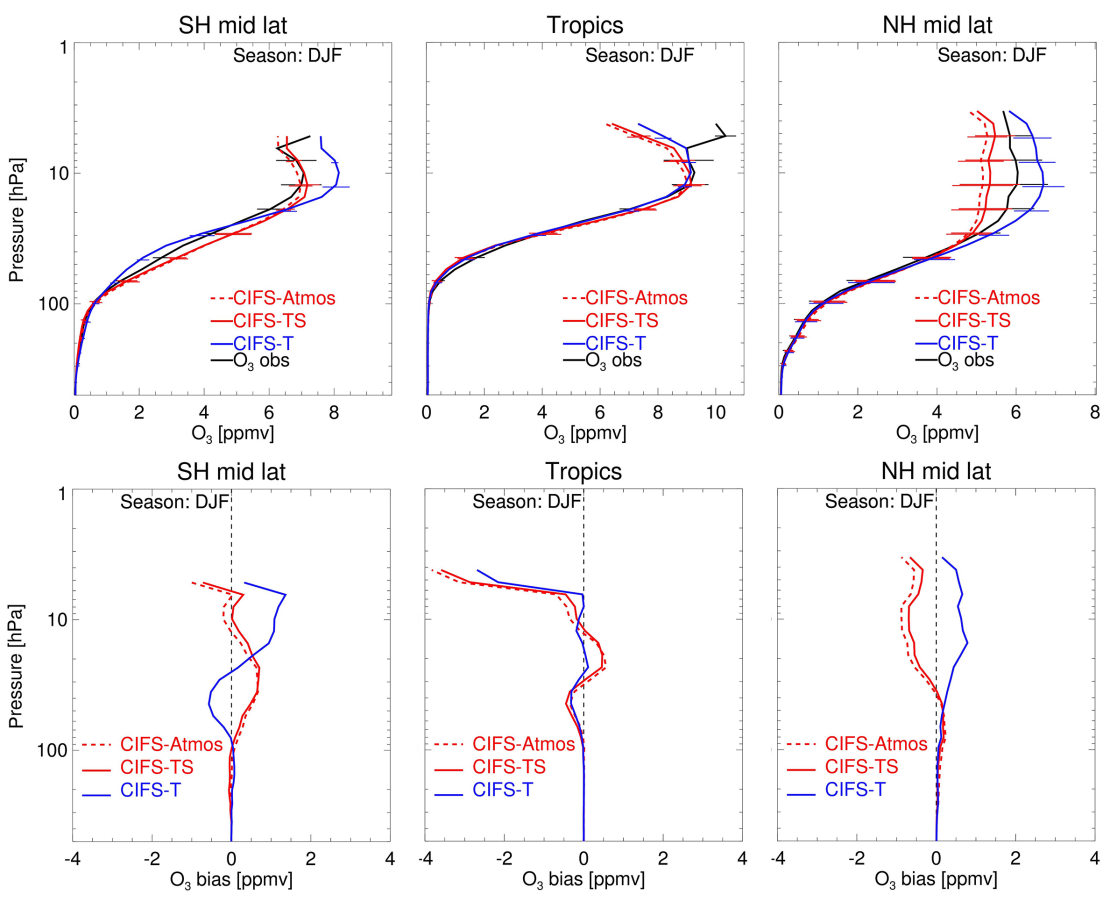

Figure 3. Top row: evaluation of ozone against WOUDC sondes over SH mid-latitudes $\left(60-30^{\circ} \mathrm{S}\right.$, left), tropics $\left(30^{\circ} \mathrm{N}-30^{\circ} \mathrm{S}\right.$, middle) and $\mathrm{NH}$ mid-latitudes $\left(30-60^{\circ} \mathrm{N}\right.$, right) for December-January-February 2009 and 2010 in units ppmv. Black: WOUDC observations; red dashed: C-IFS-Atmos; red solid: C-IFS-TS; blue: C-IFS-T. Error bars denote the $1 \sigma$ spread in the models and observations. Bottom row: corresponding mean biases.
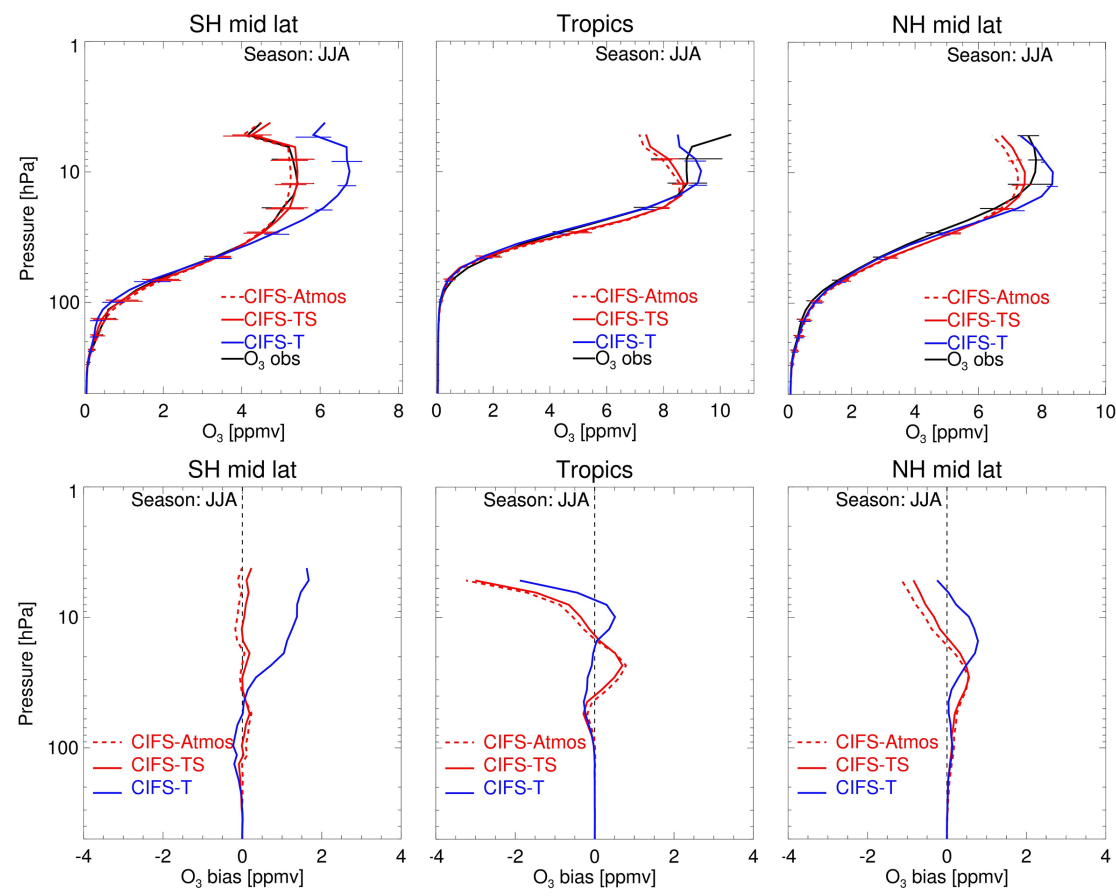

Figure 4. Same as Fig. 3 but for June-July-August 2009 and 2010. 

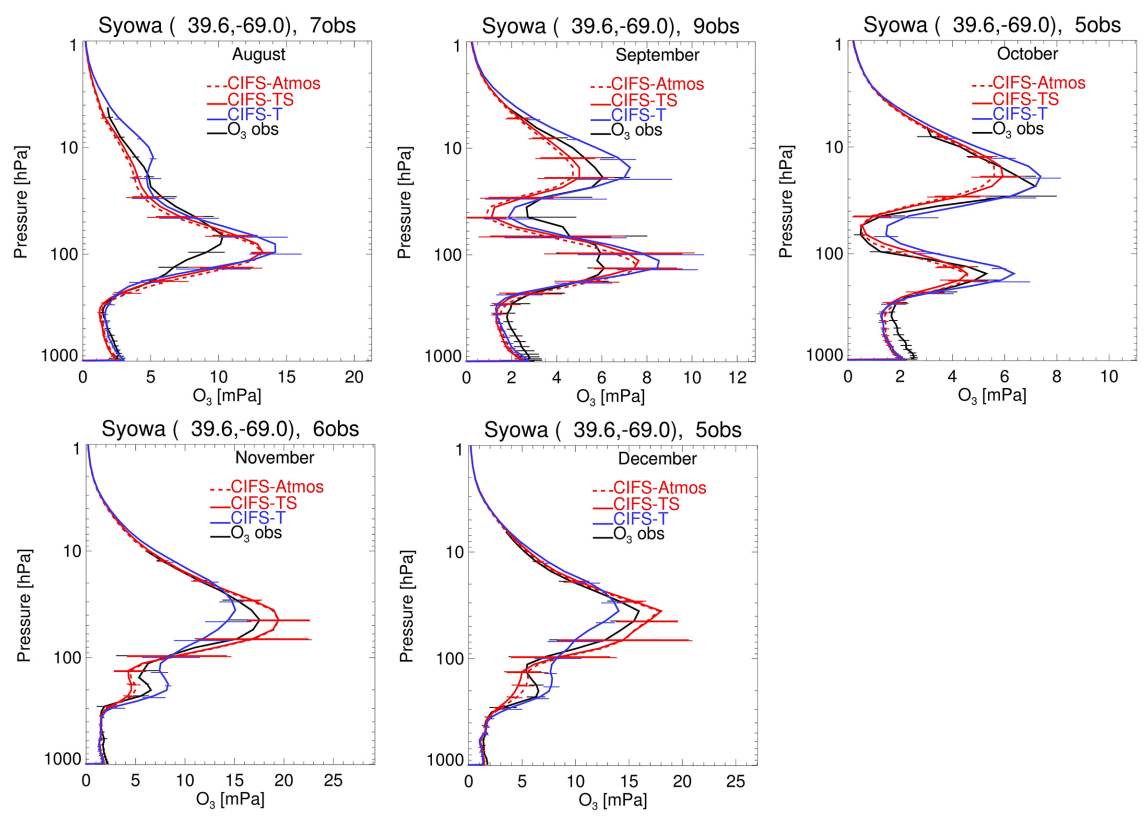

Figure 5. Evaluation of ozone in units mPa against WOUDC ozone sondes at Syowa station during August-December 2009. Black: ozone sonde; red dashed: C-IFS-Atmos; red solid: C-IFS-TS; blue: C-IFS-T. Error bars denote the $1 \sigma$ spread in the models and observations.

( $\sim 10 \mathrm{hPa}$ ), generally leading to an improvement compared to the observations. For the NH mid-latitudes this also explains the improved $\mathrm{O}_{3} \mathrm{TC}$ and $\mathrm{O}_{3} \mathrm{PC}$ in these runs compared to C-IFS-T as discussed above. Nevertheless, these experiments still show a positive bias near the ozone maximum in terms of partial pressure $(\sim 50 \mathrm{hPa})$ and also at lower altitudes during the northern hemispheric spring season. Furthermore, in the tropics the use of the full stratospheric chemistry implies a slight degradation against the linear scheme around the ozone maximum, where the Cariolle parameterization is very well tuned. The negative bias in the lower stratosphere as found in C-IFS-TS is not improved compared to C-IFS-T. These alternating biases in CIFS-TS and C-IFSAtmos are due to corresponding biases in chemically related species such as $\mathrm{NO}_{x}$ and also due to transport issues, as discussed in more detail below. The very similar performance of C-IFS-TS with respect to C-IFS-Atmos, especially in this altitude range, once again gives confidence in our approach to split chemistry schemes for tropospheric or stratospheric conditions. A similar evaluation against MLS observations, but for the period September-October-November 2009, provides very similar conclusions (Fig. S7, Supplement). For the 2009 Antarctic ozone hole season (Fig. 5) the C-IFS-TS and C-IFS-Atmos show a positive bias at $\sim 100 \mathrm{hPa}$ for August and September, and a negative bias at higher altitudes (50$10 \mathrm{hPa}$ ), where C-IFS-T shows a positive bias. Still, the depth of the ozone hole is well modelled in October. During the closure phase in November and December the $\mathrm{O}_{3}$ variability with altitude is better captured in C-IFS-TS than in C-IFS-T.

A closer analysis of the processes responsible for springtime polar ozone depletion is given in Fig. 6. In both the
C-IFS-TS and C-IFS-Atmos runs as well as BASCOE-CTM there is an $\mathrm{HNO}_{3}$ deficit at the beginning of the winter. Denitrification, which is not modelled in C-IFS-T, starts at the correct time in the models with stratospheric chemistry, indicating that NAT PSCs appear at about the right time. However, denitrification proceeds more slowly and ends 1 month later than observed by Aura-MLS. We attribute this shortcoming to the crude modelling of NAT PSCs, which does not calculate the amount of condensed nitric acid and water, keeps the surface area densities of PSC particles fixed at an arbitrary value, and parameterizes sedimentation through irreversible removal. Chlorine activation starts at exactly the right time and is as strong in the C-IFS runs as in the Aura-MLS observations until the beginning of September, but starts decreasing afterwards, while it lasts 2 more weeks in the observations. Hence the overestimation of ozone depletion during August and September in the models with explicit stratospheric chemistry is probably not due to an overestimation of chemical removal. This feature is more pronounced in CIFSTS and CIFS-Atmos than in the BASCOE-CTM, suggesting that it may be associated with differences in the modelling of transport.

The evaluation of the zonal mean ozone mixing ratios against MIPAS observations shows good general agreement (Fig. 7), with all four modelling experiments providing similar features. The tropical maximum of the $\mathrm{O}_{3}$ mixing ratio at $10 \mathrm{hPa}$ is underestimated in all experiments but to a larger extent in those which model stratospheric photochemistry explicitly (BASCOE CTM, C-IFS-TS, C-IFS-Atmos) than in C-IFS-T, in line with the evaluation against $\mathrm{O}_{3}$ sondes for June-July-August (Fig. 4). The same evaluation against 

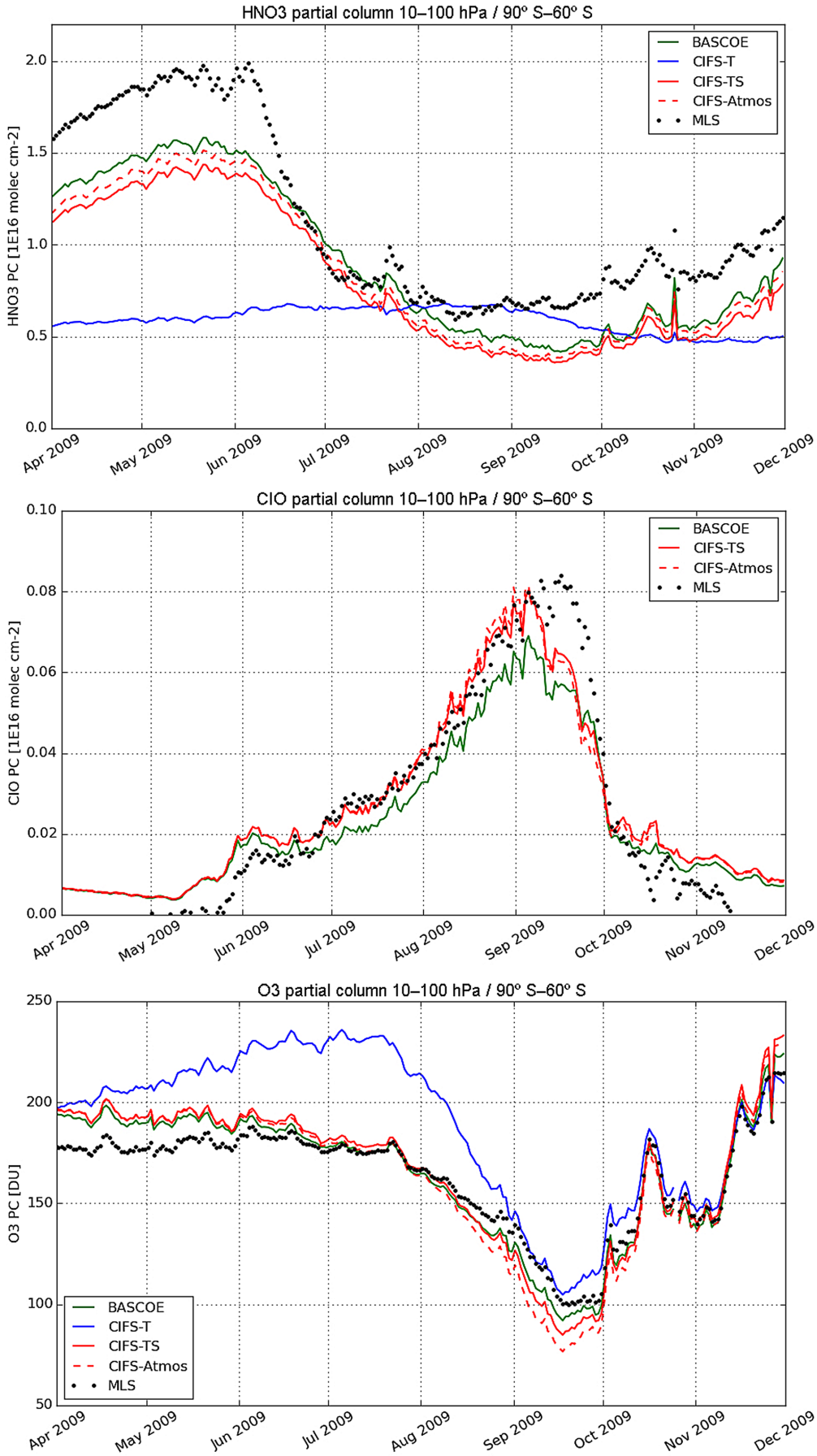

Figure 6. Daily averages of $\mathrm{O}_{3}$ partial columns $(10-100 \mathrm{hPa})$ over the Antarctic $\left(90-60^{\circ} \mathrm{S}\right)$ for the period April-November 2009 for $\mathrm{HNO}_{3}$ (top), $\mathrm{ClO}$ (middle), and $\mathrm{O}_{3}$ (bottom) against MLS observations.

MLS observations provides exactly the same conclusions (Fig. S8, Supplement).

The assessment of $\mathrm{NO}_{2}$ against MIPAS daytime $\mathrm{NO}_{2}$ observations, acquired by sampling the ascending orbits from Envisat, shows good agreement with the models, although C-IFS-TS and C-IFS-Atmos tend to show a positive bias. The C-IFS-TS and C-IFS-Atmos runs describe well the sea- sonal variation in zonal mean stratospheric $\mathrm{NO}_{2}$ columns at different latitude bands (Fig. 8), with monthly mean biases with respect to the SCIAMACHY observations of less than $1 \times 10^{15}$ molec $\mathrm{cm}^{-2}$ in the tropics and at mid-latitudes. The positive bias is larger in C-IFS-Atmos than C-IFS-TS. In contrast, poor performance can be seen for C-IFS-T, due to the lack of stratospheric $\mathrm{NO}_{x}$ chemistry in that version. 

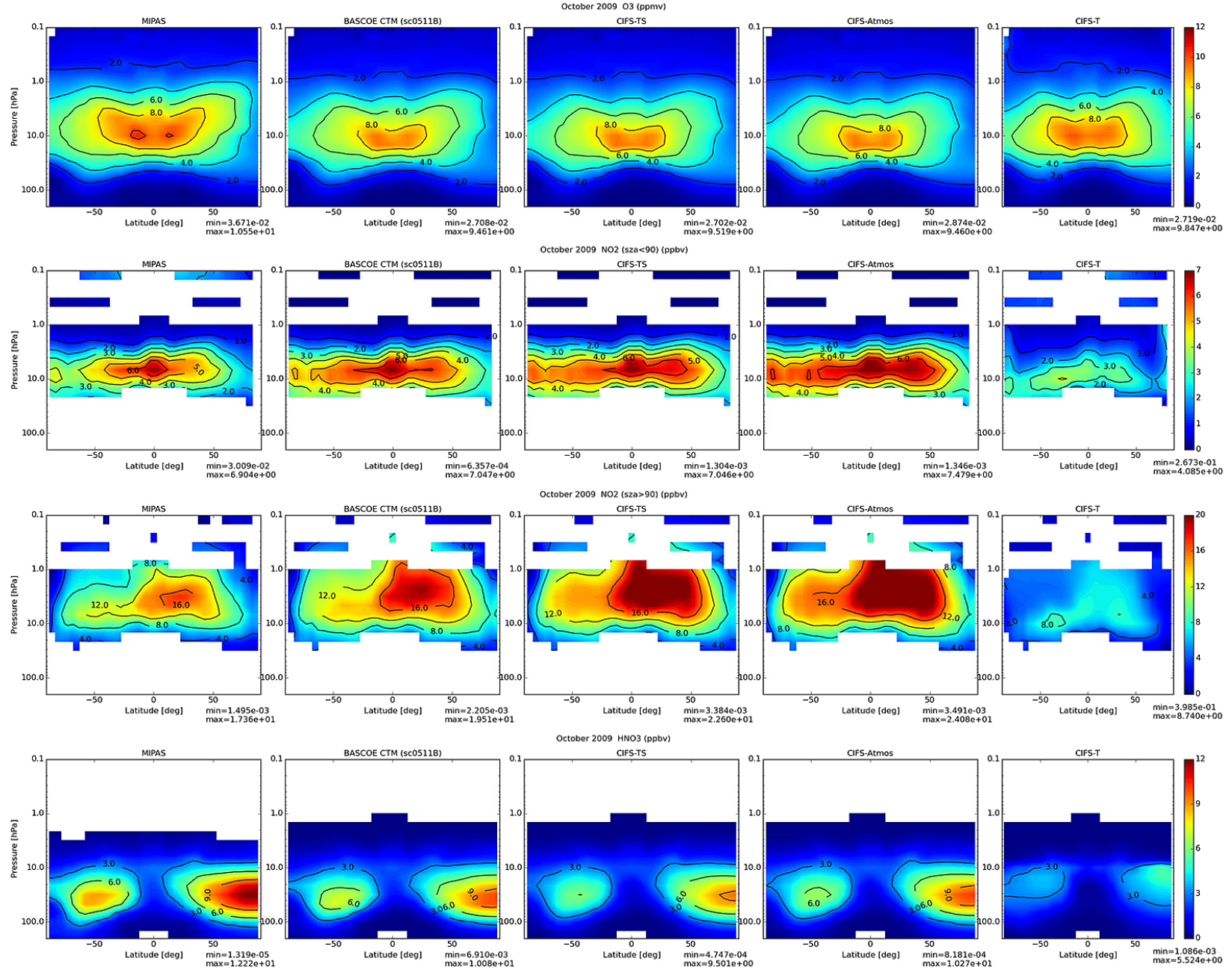

Figure 7. Zonal mean stratospheric $\mathrm{O}_{3}$ (top row, units ppmv), daytime $\mathrm{NO}_{2}$ (second row), night-time $\mathrm{NO}_{2}$ (third row) and $\mathrm{HNO}_{3}$ (bottom row, all in units ppbv) for October 2009 using MIPAS observations (first column) and co-located output of BASCOE-CTM (second), C-IFSTS (third), C-IFS-Atmos (fourth) and C-IFS-T (fifth).

However, a positive $\mathrm{NO}_{2}$ bias with respect to night-time MIPAS $\mathrm{NO}_{2}$ observations appears larger for C-IFS-TS and C-IFS-Atmos than for the BASCOE-CTM (Fig. 7). In contrast, this figure also shows a negative bias in $\mathrm{HNO}_{3}$ with respect to MIPAS observations in the BASCOE-CTM, and C-IFS-Atmos, and is even more marked in the C-IFS-TS experiment. Even though a clear improvement compared to run C-IFS-T is found, further investigation is necessary to diagnose the origins of the biases in night-time $\mathrm{NO}_{2}$ above $10 \mathrm{hPa}$ and in $\mathrm{HNO}_{3}$ between 10 and $70 \mathrm{hPa}$.

Figure 9 shows an evaluation of $\mathrm{N}_{2} \mathrm{O}$ and $\mathrm{CH}_{4}$ profiles during September 2009 against observations by ACE-FTS. Owing to their long lifetimes these trace gases are good markers for the model's ability to describe transport processes - i.e. not only the Brewer-Dobson circulation, but also isentropic mixing, mixing barriers, descent in the polar vortex, and stratosphere-troposphere exchange (Shepherd, 2007). Moreover, $\mathrm{N}_{2} \mathrm{O}$ is the main source of reactive nitrogen in the stratosphere, while $\mathrm{CH}_{4}$ is one of the main precursors of stratospheric water vapour. The figure suggests reasonable profile shapes for both $\mathrm{CH}_{4}$ and $\mathrm{N}_{2} \mathrm{O}$ in the upper stratosphere $(10 \mathrm{hPa}$ and higher), where their abundance is more strongly influenced by chemical loss but at lower altitudes (100-10 hPa). C-IFS-TS and C-IFS-Atmos show larger discrepancies in the observations than the BASCOE-CTM run, with weaker vertical gradients in the tropics and SH midlatitudes and a sharper gradient in the extra-tropical Northern Hemisphere.

This discrepancy cannot be due to different wind fields because the BASCOE-CTM experiment is driven by 3-hourly output of the C-IFS experiment. We attribute it instead to the different numerical schemes for advection and/or to differences in the representation of sub-grid transport processes in the GCM and in the CTM. Convection and diffusion are indeed explicitly modelled in C-IFS but neglected in the BASCOE CTM, which relies on the implicit diffusion proper- 

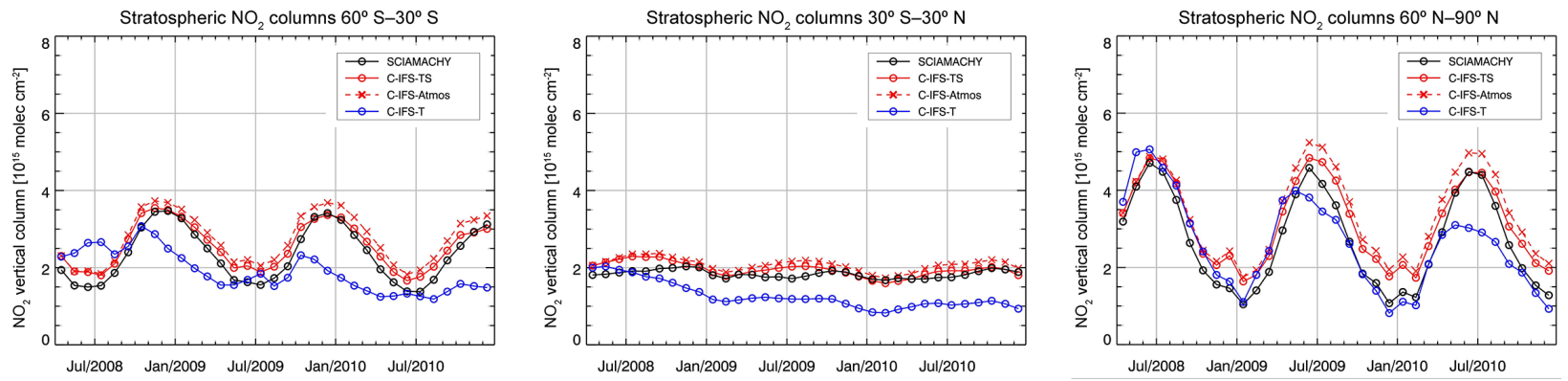

Figure 8. Time series of total column $\mathrm{NO}_{2}$ above the clean Pacific Ocean $\left(180-220^{\circ} \mathrm{E}\right)$ for April 2008-December 2010, in units $10^{15}$ molec $\mathrm{cm}^{-2}$ for NH mid-latitudes (left), tropics (middle) and SH mid-latitudes (right). Black: SCIAMACHY observations; red dashed: C-IFS-Atmos; red solid: C-IFS-TS; blue: C-IFS-T.

ties of its flux-form advection scheme to represent sub-grid mixing (Lin and Rood, 1996; Jablonowski and Williamson, 2011). Since lower stratospheric ozone is strongly determined by both chemistry and transport, the transport issue indicated by Fig. 9 could also contribute directly to the ozone biases seen below $10 \mathrm{hPa}$ in Figs. 3 and 4.

Figure 10 shows a good consistency between $\mathrm{H}_{2} \mathrm{O}$ modelled by C-IFS-TS and the BASCOE-CTM results, albeit with a slight negative bias with respect to MLS observations above $5 \mathrm{hPa}$ and a positive bias around $30 \mathrm{hPa}$ in the tropics, associated with corresponding biases in $\mathrm{CH}_{4}$. This figure also shows globally a good agreement between $\mathrm{HCl}$ modelled by C-IFS-TS and MLS observations, although with a positive bias of $0.8 \mathrm{ppbv}$ confined in the region of ozone depletion above Antarctica.

\section{Conclusions}

We have presented a model description and benchmark evaluation of an extension of the C-IFS system with stratospheric ozone chemistry of the BASCOE model added to already existing tropospheric scheme CB05. We refer to this system as C-IFS-CB05-BASCOE, or C-IFS-TS for short. In our approach we have retained a separate treatment for tropospheric and stratospheric chemistry, and select the most appropriate scheme depending on the altitude with respect to the tropopause level. This has the advantage that mechanisms which are optimized for tropospheric and stratospheric chemistry, respectively, can be retained, which also substantially reduces the computational costs of the chemical solver compared to an approach where all reactions are activated in the whole atmosphere, referred to as C-IFS-Atmos. Also, it allows for an easy switch between system set-ups. To avoid jumps in trace gas concentrations at the interface, the consistency in gas-phase reaction rates has been verified, while the photolysis rates from the two parameterizations are interpolated across the interface. We showed that differences between C-IFS-TS and C-IFS-Atmos are overall small; hence, our basic assumption of having different chemistry solvers for troposphere and stratosphere is valid for our applications.

An evaluation of a 2.5-year simulation of C-IFS-TS indicates good performance of the system in terms of stratospheric ozone, of similar quality as its ancestor BASCOECTM model results, and a considerable general improvement in terms of stratospheric composition compared to the C-IFS$\mathrm{T}$ predecessor model version which applied a linear ozone scheme in the stratosphere.

The $\mathrm{O}_{3}$ partial columns $(10-100 \mathrm{hPa})$ show biases mostly smaller than \pm 20 DU when compared to the Aura MLS observations. Also, the profiles were generally well captured, and show an improvement with respect to the C-IFS-T linear ozone scheme in the stratosphere over mid-latitudes. The depth and variability of the ozone hole over Antarctica is modelled well. While the C-IFS-T also shows a remarkably good agreement with the observations during the ozone hole episodes, it develops a significant overestimation of the partial columns during other months. The tropical maximum of the mixing ratio, around $10 \mathrm{hPa}$, is the only stratospheric region where C-IFS-T agrees better all-year-long with observations.

Also, evaluation of other trace gases $\left(\mathrm{NO}_{2}, \mathrm{HNO}_{3}, \mathrm{CH}_{4}\right.$, $\mathrm{N}_{2} \mathrm{O}, \mathrm{HCl}$ ) against observations derived from various satellite retrievals (SCIAMACHY, ACE-FTS, MIPAS, MLS) illustrates the clear improvements obtained with C-IFS-TS compared to C-IFS-T, even though C-IFS-TS still suffers from positive biases in stratospheric $\mathrm{NO}_{2}$, whereas $\mathrm{HNO}_{3}$ is biased low. For the long-lived tracers $\mathrm{CH}_{4}$ and $\mathrm{N}_{2} \mathrm{O}$, larger errors with respect to limb-sounding retrievals were found between 10 and $100 \mathrm{hPa}$ than with the BASCOE-CTM, suggesting difficulties in representing slow transport processes. The BASCOE-CTM experiment shown here was driven by 3-hourly wind field output of the C-IFS experiments. Hence this discrepancy is due to a difference in the representation of the transport processes between the GCM and the CTM, i.e. the numerical scheme used for advection (semi-Lagrangian vs. flux-form), the convection (parameterized in C-IFS but neglected in BASCOE CTM) or the diffusion (parameterized 

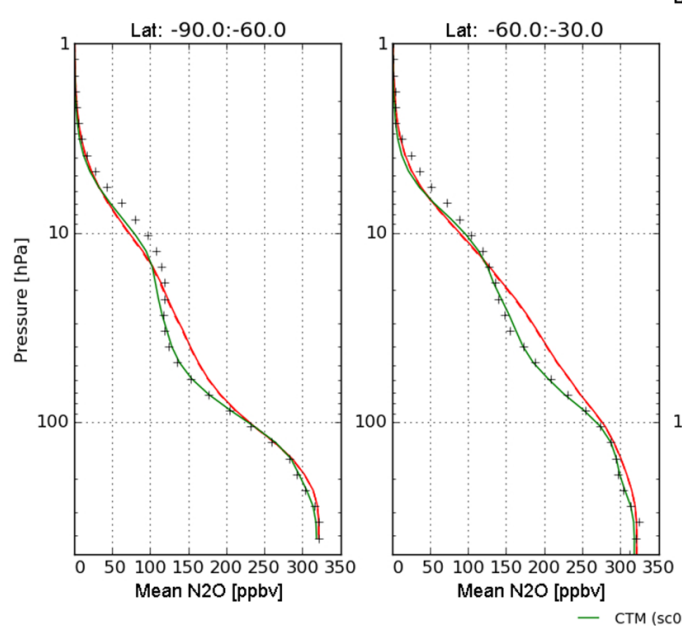

Dates: $01.09 .2009-30.11 .2009$
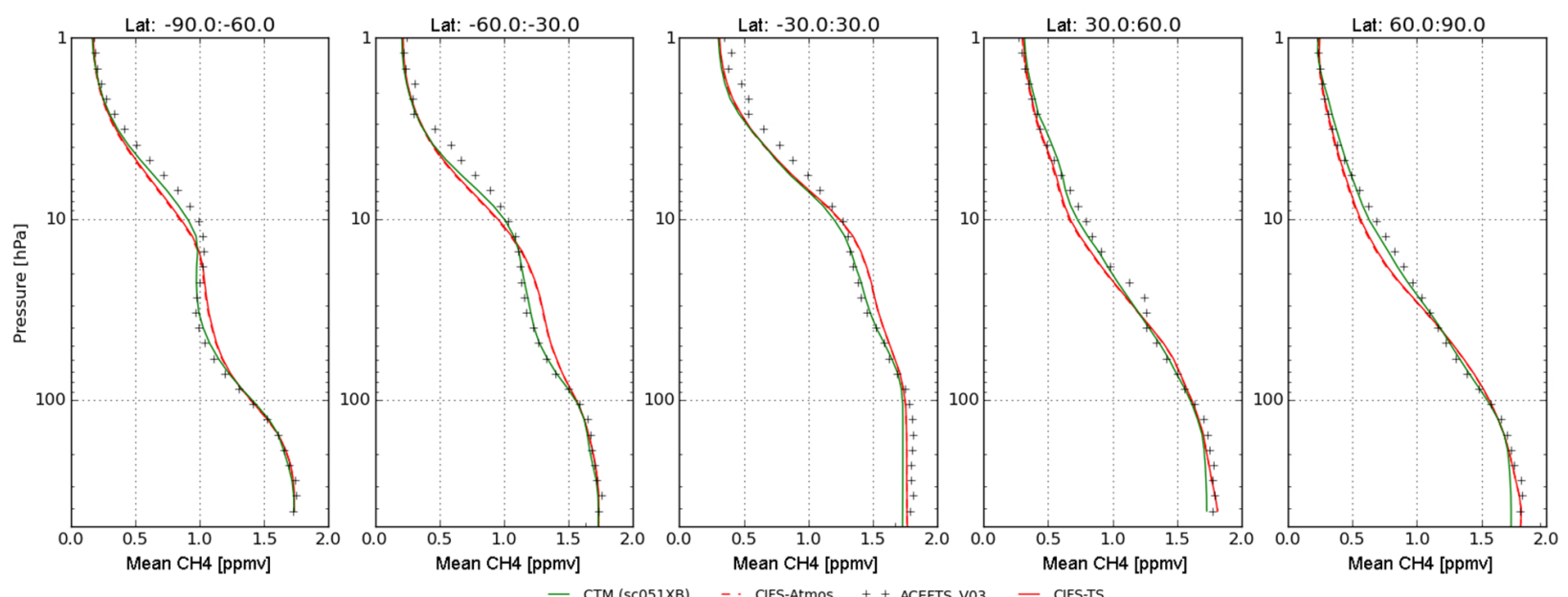

Figure 9. Zonal mean profiles of stratospheric $\mathrm{N}_{2} \mathrm{O}$ (top) and $\mathrm{CH}_{4}$ (bottom) for September-October-November 2009 using ACE-FTS observations (black symbols) and co-located output of BASCOE-CTM (green lines), C-IFS-TS (red solid lines) and C-IFS-Atmos (red dashed lines). The zonal means are shown separately in five columns corresponding to the latitude bands $90-60^{\circ} \mathrm{S}, 60-30^{\circ} \mathrm{S}, 30^{\circ} \mathrm{S}-30^{\circ} \mathrm{N}$, $30-60^{\circ} \mathrm{N}$ and $60-90^{\circ} \mathrm{N}$, respectively.

in C-IFS but not explicitly considered in the CTM). Hence, stratospheric transport in C-IFS will be an area for further evaluation and developments.

This benchmark model evaluation of C-IFS-TS marks a key step towards merging tropospheric and stratospheric chemistry within IFS, aiming at a possible configuration for daily operational forecasts of lower and middle atmospheric composition in the near future. Future work could focus on the following aspects.

- Chemical data assimilation: initial tests with data assimilation of $\mathrm{O}_{3}$ total column and profile retrievals suggest that stratospheric ozone is successfully constrained in C-IFS-TS. However, observational constraints on other components driving ozone chemistry are currently lacking in the assimilation system. Our extension opens the possibility of assimilation of additional trace gases such as $\mathrm{N}_{2} \mathrm{O}$ and $\mathrm{HCl}$. However, for the 4D-VAR assimilation of short-lived species such as $\mathrm{NO}_{2}$ and $\mathrm{ClO}$, an adjoint chemistry module would likely be required as implemented in the BASCOE data assimilation system.

- Alignment of the reaction mechanism and photolysis rates: while at the current stage the gas-phase and photolytic reaction rates of the parent schemes are retained, we foresee a further integration to ensure better alignment of the chemical mechanisms. Especially the existing jumps in photolysis rates as a consequence of the different parameterizations are not desirable, even though they are not harmful to model stability or visibly lead to any degradation in model performance. The alignment in terms of gas-phase reaction rate expressions can be achieved by the introduction of the KPP solver in C-IFS, for both tropospheric and stratospheric 

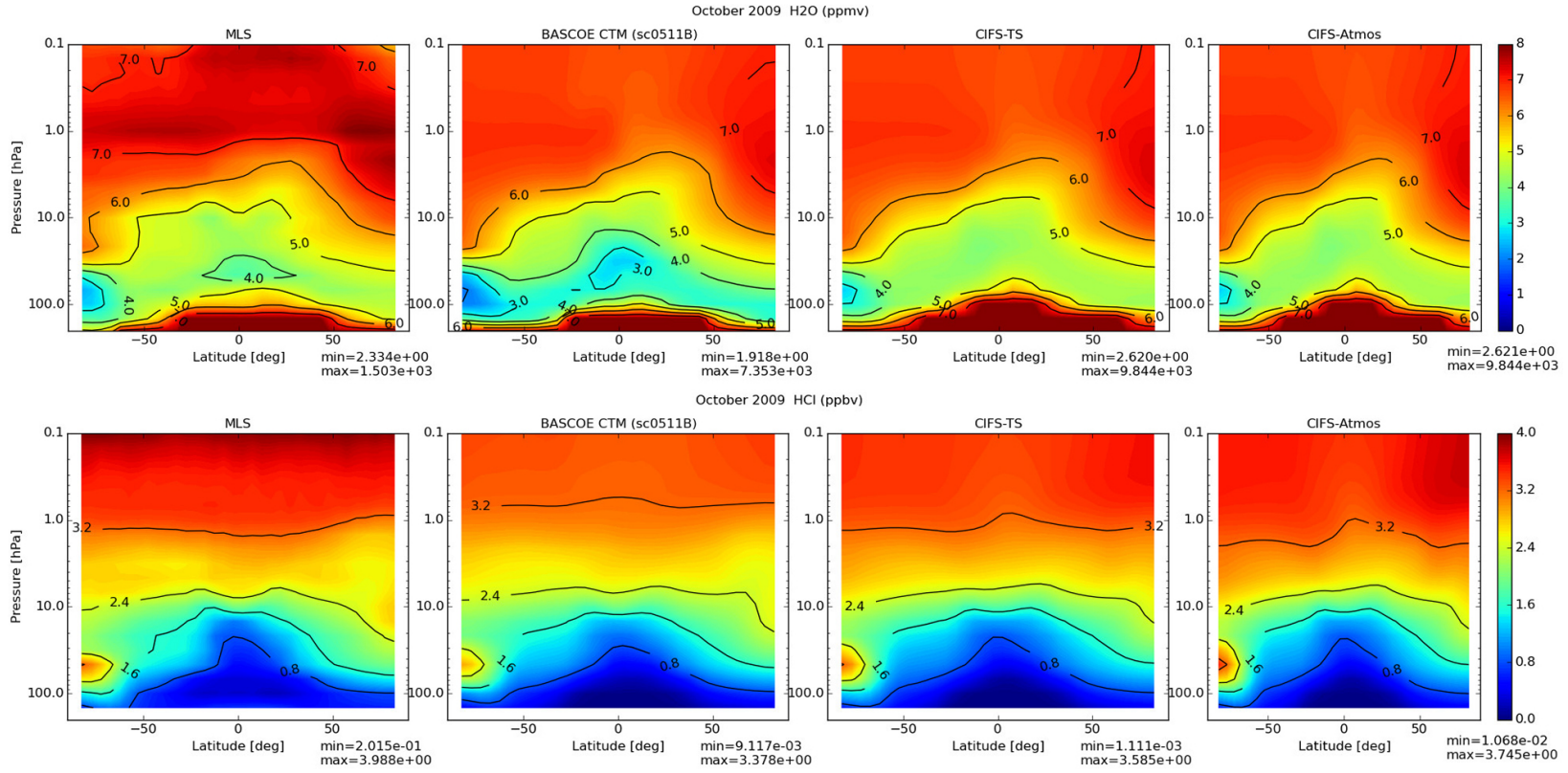

Figure 10. Zonal mean stratospheric $\mathrm{H}_{2} \mathrm{O}$ (top, units ppmv) and $\mathrm{HCl}$ (bottom, units ppbv) for October 2009 using Aura/MLS observations (first column) and co-located output of BASCOE-CTM (second), C-IFS-TS (third) and C-IFS-Atmos (fourth).

chemistry, which allows for a better traceable model development than the hard-coded Euler backward integration (EBI) solver as adopted in Flemming et al. (2015).

- Improvement of the representation of stratospheric sulfate aerosols and polar stratospheric clouds: the current climatology for these aerosols and parameterization for PSCs could easily be improved. While the current results are satisfactory for a general-purpose monitoring system, these improvements would especially allow better simulations of the composition in the polar lower stratosphere during springtime.

- Extension of tropospheric and stratospheric chemistry schemes: the availability of a comprehensive set of trace gas fields allows for a relatively easy extension of the tropospheric reaction mechanism by including selective reactions originating from the stratospheric chemistry, and vice versa. Examples are the introduction of halogen chemistry into the troposphere (von Glasow and Crutzen, 2007), or $\mathrm{SO}_{2}$ conversion to sulfate aerosol in the stratosphere, relevant in case of strong volcanic events (Bândă, et al., 2016).

- Optimization of solver efficiency: even though the use of the KPP has simplified the code maintenance and may result in a higher numerical accuracy of the solution, it also caused a considerable slow-down of the numerical efficiency as compared to the EBI solver, as that solver had been optimized for tropospheric ozone chemistry in C-IFS-CB05. Solutions could be an optimization of the initial chemical time step for the KPP solver, depending on prevailing chemical and physical conditions, and an optimization of the automated solver code, which allows for a more efficient code structure (KP4, Jöckel et al., 2010).

In summary, the extension towards stratospheric chemistry in C-IFS broadens its ability for forecast and assimilation of stratospheric composition, which is beneficial to the monitoring capabilities in CAMS, and may also contribute to advances in meteorological forecasting of the ECMWF IFS model in the future.

\section{Code availability}

The C-IFS source code is integrated into ECWMF's IFS code, which is available subject to a licence agreement with ECMWF; see also Flemming et al. (2015) for details. The stratospheric chemistry module of C-IFS was originally developed in the framework of BASCOE. Readers interested in the BASCOE code can contact the developers through http://bascoe.oma.be (BASCOE code, 2016). 


\section{Appendix A}

Table A1. Trace gases in C-IFS-TS, along with their chemically active domain: troposphere (Trop), stratosphere (Strat) or whole atmosphere (WA).

\begin{tabular}{|c|c|c|}
\hline Short name & Long name & $\begin{array}{l}\text { Active } \\
\text { domain }\end{array}$ \\
\hline $\mathrm{O} 3$ & ozone & WA \\
\hline $\mathrm{OH}$ & hydroxyl radical & WA \\
\hline $\mathrm{H} 2 \mathrm{O} 2$ & hydrogen peroxide & WA \\
\hline $\mathrm{HO} 2$ & hydroperoxy radical & WA \\
\hline $\mathrm{CO}$ & carbon monoxide & WA \\
\hline $\mathrm{CH} 2 \mathrm{O}$ & formaldehyde & WA \\
\hline $\mathrm{CH} 3 \mathrm{O} 2$ & methylperoxy radical & WA \\
\hline $\mathrm{CH} 3 \mathrm{OOH}$ & methylperoxide & WA \\
\hline $\mathrm{CH} 4$ & methane & WA \\
\hline NO & nitrogen monoxide & WA \\
\hline $\mathrm{NO} 2$ & nitrogen dioxide & WA \\
\hline NO3 & nitrate radical & WA \\
\hline HNO3 & nitric acid & WA \\
\hline $\mathrm{HO} 2 \mathrm{NO} 2$ & pernitric acid & WA \\
\hline N2O5 & dinitrogen pentoxide & WA \\
\hline $\mathrm{Rn}$ & radon & WA \\
\hline $\mathrm{Pb}$ & lead & Trop \\
\hline $\mathrm{C} 2 \mathrm{H} 4$ & ethene & Trop \\
\hline $\mathrm{C} 2 \mathrm{H} 6$ & ethane & Trop \\
\hline $\mathrm{C} 2 \mathrm{H} 5 \mathrm{OH}$ & ethanol & Trop \\
\hline C3H8 & propane & Trop \\
\hline C3H6 & propene & Trop \\
\hline C5H8 & isoprene & Trop \\
\hline C10H16 & terpenes & Trop \\
\hline СН3СOCHO & methylglyoxal & Trop \\
\hline СH3СOCH3 & acetone & Trop \\
\hline $\mathrm{CH} 3 \mathrm{OH}$ & methanol & Trop \\
\hline $\mathrm{HCOOH}$ & formic acid & Trop \\
\hline $\mathrm{MCOOH}$ & methacrylic acid & Trop \\
\hline PAR & paraffins & Trop \\
\hline OLE & olefins & Trop \\
\hline ALD2 & aldehydes & Trop \\
\hline $\mathrm{ROOH}$ & peroxides & Trop \\
\hline PAN & peroxyacetyl nitrate & Trop \\
\hline ONIT & organic nitrates & Trop \\
\hline $\mathrm{SO} 2$ & sulfur dioxide & Trop \\
\hline $\mathrm{SO} 4$ & sulfate & Trop \\
\hline DMS & dimethyl sulfide & Trop \\
\hline MSA & methanesulfonic acid & Trop \\
\hline NO3_A & nitrate & Trop \\
\hline $\mathrm{NH} 2$ & amine & Trop \\
\hline NH3 & ammonia & Trop \\
\hline NH4 & ammonium & Trop \\
\hline $\mathrm{C} 2 \mathrm{O} 3$ & peroxyacetyl radical & Trop \\
\hline ISPD & methacrolein MVK & Trop \\
\hline $\mathrm{ACO} 2$ & acetone product & Trop \\
\hline
\end{tabular}

Table A1. Continued.

\begin{tabular}{|c|c|c|}
\hline Short name & Long name & $\begin{array}{l}\text { Active } \\
\text { domain }\end{array}$ \\
\hline IC3H7O2 & $\mathrm{IC} 3 \mathrm{H} 7 \mathrm{O} 2$ & Trop \\
\hline HYPROPO2 & HYPROPO2 & Trop \\
\hline ROR & organic ethers & Trop \\
\hline RXPAR & PAR budget corrector & Trop \\
\hline $\mathrm{XO} 2$ & NO to NO2 operator & Trop \\
\hline $\mathrm{XO} 2 \mathrm{~N}$ & NO to alkyl nitrate operator & Trop \\
\hline $\mathrm{O}$ & oxygen atom (ground state) & Strat \\
\hline O1D & oxygen atom (first excited) state) & Strat \\
\hline $\mathrm{H}$ & hydrogen atom & Strat \\
\hline $\mathrm{H} 2$ & hydrogen & Strat \\
\hline $\mathrm{H} 2 \mathrm{O}$ & water & Strat \\
\hline $\mathrm{CH} 3$ & methyl radical & Strat \\
\hline $\mathrm{CH} 3 \mathrm{O}$ & methoxy radical & Strat \\
\hline $\mathrm{HCO}$ & formyl radical & Strat \\
\hline $\mathrm{CO} 2$ & carbon dioxide & Strat \\
\hline $\mathrm{N}$ & nitrogen atom & Strat \\
\hline $\mathrm{N} 2 \mathrm{O}$ & nitrous oxide & Strat \\
\hline CL & chlorine atom & Strat \\
\hline CL2 & chlorine & Strat \\
\hline HCL & hydrogen chloride & Strat \\
\hline HOCL & hypochlorous acid & Strat \\
\hline CH3CL & methyl chloride & Strat \\
\hline CH3CCL3 & methyl chloroform & Strat \\
\hline CCL4 & tetrachloromethane & Strat \\
\hline CLONO2 & chlorine_nitrate & Strat \\
\hline CLNO2 & chloro(oxo)azane oxide & Strat \\
\hline CLO & chlorine monoxide & Strat \\
\hline OCLO & chlorine dioxide & Strat \\
\hline CLOO & asymmetric chlorine dioxide radical & Strat \\
\hline CL2O2 & dichlorine_dioxide & Strat \\
\hline $\mathrm{BR}$ & bromine atom & Strat \\
\hline $\mathrm{BR} 2$ & bromine atomic ground state & Strat \\
\hline CH3BR & methyl bromide & Strat \\
\hline $\mathrm{CH} 2 \mathrm{BR} 2$ & dibromomethane & Strat \\
\hline CHBR3 & bromoform & Strat \\
\hline BRONO2 & bromine nitrate & Strat \\
\hline $\mathrm{BRO}$ & bromine monoxide & Strat \\
\hline HBR & hydrogen bromide & Strat \\
\hline HOBR & hypobromous acid & Strat \\
\hline BRCL & bromine monochloride & Strat \\
\hline $\mathrm{HF}$ & hydrofluoric acid & Strat \\
\hline CFC11 & trichlorofluoromethane & Strat \\
\hline CFC12 & dichlorodifluoromethane & Strat \\
\hline CFC113 & trichlorotrifluoroethane & Strat \\
\hline CFC114 & 1,2-dichlorotetrafluoroethane & Strat \\
\hline CFC115 & chloropentafluoroethane & Strat \\
\hline $\mathrm{HCFC} 22$ & chlorodifluoromethane & Strat \\
\hline HA1301 & bromotrifluoromethane & Strat \\
\hline HA1211 & bromochlorodifluoromethane & Strat \\
\hline
\end{tabular}




\section{The Supplement related to this article is available online at doi:10.5194/gmd-9-3071-2016-supplement.}

Acknowledgements. MACC III was funded by the European Union's Seventh Framework Programme (FP7) under grant agreement no. 283576. We are grateful to the World Ozone and Ultraviolet Radiation Data Centre (WOUDC) for providing ozone sonde observations and to the GOME-2, MIPAS, ACE-FTS and MLS teams for providing satellite observations. We thank two anonymous reviewers for their useful comments on the original manuscript.

Edited by: V. Grewe

Reviewed by: two anonymous referees

\section{References}

Atkinson, R., Baulch, D. L., Cox, R. A., Crowley, J. N., Hampson, R. F., Hynes, R. G., Jenkin, M. E., Rossi, M. J., Troe, J., and IUPAC Subcommittee: Evaluated kinetic and photochemical data for atmospheric chemistry: Volume II - gas phase reactions of organic species, Atmos. Chem. Phys., 6, 3625-4055, doi:10.5194/acp-6-3625-2006, 2006.

Baldwin, M. P., Gray, L. J., Dunkerton, T. J., Hamilton, K., Haynes, P. H., Randel, W. J., Holton, J. R., Alexander, M. J., Hirota, I., Horinouchi, T., Jones, D. B. A., Kinnersley, J. S., Marquardt, C., Sato, K., and Takahashi, M.: The quasi-biennial oscillation, Rev. Geophys., 39, 179-229, doi:10.1029/1999RG000073, 2001.

Bândă, N., Krol, M., van Weele, M., van Noije, T., Le Sager, P., and Röckmann, T.: Can we explain the observed methane variability after the Mount Pinatubo eruption?, Atmos. Chem. Phys., 16, 195-214, doi:10.5194/acp-16-195-2016, 2016.

BASCOE code: Belgian Assimilation System for Chemical ObsErvations (BASCOE), available at: http://bascoe.oma.be, last access: 31 August 2016.

Benedetti, A., Morcrette, J.-J., Boucher, O., Dethof, A., Engelen, R. J., Fisher, M., Flentje, H., Huneeus, N., Jones, L., Kaiser, J. W., Kinne, S., Mangold, A., Razinger, M., Simmons, A. J., Suttie, M., and the GEMS-AER team: Aerosol analysis and forecast in the European Centre for Medium-Range Weather Forecasts Integrated Forecast System: 2. Data assimilation, J. Geophys. Res., 114, D13205, doi:10.1029/2008JD011115, 2009.

Boone, C. D., Nassar, R., Walker, K. A., Rochon, Y., McLood, S. D., Rinsland, C. P., and Bernath, P. F.: Retrievals for the atmospheric chemistry experiment Fourier-transform spectrometer, Appl. Optics, 44, 7218-7231, 2005.

Bovensmann, H., Burrows, J. P., Buchwitz, M., Frerick, J., Noël, S., Rozanov, V. V., Chance, K. V., and Goede, A. P. H.: SCIAMACHY: Mission Objectives and Measurement Modes, J. Atmos. Sci., 56, 127-150, doi:10.1175/15200469(1999)056<0127:SMOAMM>2.0.CO;2, 1999.

Brasseur, G., Smith, A., Khosravi, R., Huang, T., Walters, S., Chabrillat, S., and Kockarts, G.: Natural and human-induced perturbations in the middle atmosphere: A short tutorial, In Atmospheric Science Across the Stratopause, 7-20, AGU Geophys. Monograph, Vol. 123, doi:10.1029/GM123p0007, 2000.
Cariolle, D. and Morcrette, J.-J.: A linearized approach to the radiative budget of the stratosphere: Influence of the ozone distribution, Geophys. Res. Lett., 33, L05806, doi:10.1029/2005GL025597, 2006.

Cariolle, D. and Teyssèdre, H.: A revised linear ozone photochemistry parameterization for use in transport and general circulation models: multi-annual simulations, Atmos. Chem. Phys., 7, 2183 2196, doi:10.5194/acp-7-2183-2007, 2007.

Ceccherini, S., Cortesi, U., Verronen, P. T., and Kyrölä, E.: Technical Note: Continuity of MIPAS-ENVISAT operational ozone data quality from full- to reduced-spectral-resolution operation mode, Atmos. Chem. Phys., 8, 2201-2212, doi:10.5194/acp-82201-2008, 2008.

Chabrillat, S. and Fonteyn, D.: Modelling long-term changes of mesospheric temperature and chemistry, Adv. Space Res., 32, 1689-1700, doi:10.1016/S0273-1177(03)90464-9, 2003.

Chipperfield, M. P., Dhomse, S. S., Feng, W., McKenzie, R. L., Velders, G. J. M., and Pyle, J. A.: Quantifying the ozone and ultraviolet benefits already achieved by the Montreal Protocol, Nat Commun., 6, 7233, doi:10.1038/ncomms8233, 2015.

de Grandpré, J., Ménard, R., Rochon, Y., Charette, C., Chabrillat, S., and Robichaud, A.: Radiative impact of ozone on temperature predictability in a coupled chemistry-dynamics data assimilation system, Mon. Weather Rev., 137, 679-692, doi:10.1175/2008MWR2572.1, 2009.

de Grandpré, J., Tanguay, M., Qaddouri, A., Zerroukat, M., and McLinden, C. A.: Semi-Lagrangian Advection of Stratospheric Ozone on a Yin-Yang Grid System, Mon. Weather Rev., 144, 1035-1050, doi:10.1175/MWR-D-15-0142.1, 2016.

De Mazière, M., Vigouroux, C., Bernath, P. F., Baron, P., Blumenstock, T., Boone, C., Brogniez, C., Catoire, V., Coffey, M., Duchatelet, P., Griffith, D., Hannigan, J., Kasai, Y., Kramer, I., Jones, N., Mahieu, E., Manney, G. L., Piccolo, C., Randall, C., Robert, C., Senten, C., Strong, K., Taylor, J., Tétard, C., Walker, K. A., and Wood, S.: Validation of ACE-FTS v2.2 methane profiles from the upper troposphere to the lower mesosphere, Atmos. Chem. Phys., 8, 2421-2435, doi:10.5194/acp-8-2421-2008, 2008.

Diamantakis, M. and Flemming, J.: Global mass fixer algorithms for conservative tracer transport in the ECMWF model, Geosci. Model Dev., 7, 965-979, doi:10.5194/gmd-7-965-2014, 2014.

ECMWF: IFS documentation - Cy41r1. Operational implementation 12 May 2015, available at: http://www.ecmwf.int/en/ forecasts/documentation-and-support/changes-ecmwf-model/ ifs-documentation (last access: 5 July 2016), 2015.

Engelen, R. J., Serrar, S., and Chevallier, F.: Four-dimensional data assimilation of atmospheric $\mathrm{CO}_{2}$ using AIRS observations, J. Geophys. Res., 114, D03303, doi:10.1029/2008JD010739, 2009.

Errera, Q. and Fonteyn, D.: Four-dimensional variational chemical assimilation of CRISTA stratospheric measurements, J. Geophys. Res., 106, 12253-12265, doi:10.1029/2001JD900010, 2001.

Errera, Q., Daerden, F., Chabrillat, S., Lambert, J. C., Lahoz, W. A., Viscardy, S., Bonjean, S., and Fonteyn, D.: 4D-Var assimilation of MIPAS chemical observations: ozone and nitrogen dioxide analyses, Atmos. Chem. Phys., 8, 6169-6187, doi:10.5194/acp8-6169-2008, 2008.

Eskes, H., Huijnen, V., Arola, A., Benedictow, A., Blechschmidt, A.-M., Botek, E., Boucher, O., Bouarar, I., Chabrillat, S., Cuevas, 
E., Engelen, R., Flentje, H., Gaudel, A., Griesfeller, J., Jones, L., Kapsomenakis, J., Katragkou, E., Kinne, S., Langerock, B., Razinger, M., Richter, A., Schultz, M., Schulz, M., Sudarchikova, N., Thouret, V., Vrekoussis, M., Wagner, A., and Zerefos, C.: Validation of reactive gases and aerosols in the MACC global analysis and forecast system, Geosci. Model Dev., 8, 3523-3543, doi:10.5194/gmd-8-3523-2015, 2015.

Flemming, J. and Huijnen, V.: IFS Tracer Transport Study, MACC Deliverable G-RG 4.2, Tech. rep., ECMWF, available at: http://www.gmes-atmosphere.eu/documents/deliverables/g-rg/ ifs_transport_study.pdf (last access: 15 December 2015), 2011.

Flemming, J., Inness, A., Jones, L., Eskes, H. J., Huijnen, V., Schultz, M. G., Stein, O., Cariolle, D., Kinnison, D., and Brasseur, G.: Forecasts and assimilation experiments of the Antarctic ozone hole 2008, Atmos. Chem. Phys., 11, 1961-1977, doi:10.5194/acp-11-1961-2011, 2011.

Flemming, J., Huijnen, V., Arteta, J., Bechtold, P., Beljaars, A., Blechschmidt, A.-M., Diamantakis, M., Engelen, R. J., Gaudel, A., Inness, A., Jones, L., Josse, B., Katragkou, E., Marecal, V., Peuch, V.-H., Richter, A., Schultz, M. G., Stein, O., and Tsikerdekis, A.: Tropospheric chemistry in the Integrated Forecasting System of ECMWF, Geosci. Model Dev., 8, 975-1003, doi:10.5194/gmd-8-975-2015, 2015.

Fonteyn, D. and Larsen, N.: Detailed PSC formation in a twodimensional chemical transport model of the stratosphere, Ann. Geophys., 14, 315-328, doi:10.1007/s00585-996-0315-0, 1996.

Froidevaux, L., Jiang, Y. B., Lambert, A., Livesey, N. J., Read, W. G., Waters, J. W., Browell, E. V., Hair, J. W., Avery, M. A., McGee, T. J., Twigg, L. W., Sumnicht, G. K., Jucks, K. W., Margitan, J. J., Sen, B., Stachnik, R. A., Toon, G. C., Bernath, P. F., Boone, C. D., Walker, K. A., Filipiak, M. J., Harwood, R. S., Fuller, R. A., Manney, G. L., Schwartz, M. J., Daffer, W. H., Drouin, B. J., Cofield, R. E., Cuddy, D. T., Jarnot, R. F., Knosp, B. W., Perun, V. S., Snyder, W. V., Stek, P. C., Thurstans, R. P., and Wagner, P. A.: Validation of Aura Microwave Limb Sounder stratospheric ozone measurements, J. Geophys. Res., 113, D15S20, doi:10.1029/2007JD008771, 2008a.

Froidevaux, L., Jiang, Y. B., Lambert, A., Livesey, N. J., Read, W. G., Waters, J. W., Fuller, R. A., Marcy, T. P., Popp, P. J., Gao, R. S., Fahey, D. W., Jucks, K. W., Stachnik, R. A., Toon, G. C., Christensen, L. E., Webster, C. R., Bernath, P. F., Boone, C. D., Walker, K. A., Pumphrey, H. C., Harwood, R. S., Manney, G. L., Schwartz, M. J., Daffer, W. H., Drouin, B. J., Cofield, R. E., Cuddy, D. T., Jarnot, R. F., Knosp, B. W., Perun, V. S., Snyder, W. V., Stek, P. C., Thurstans, R. P., and Wagner, P. A.: Validation of Aura microwave limb sounder $\mathrm{HCl}$ measurements, J. Geophys. Res.-Atmos., 113, D15S25, doi:10.1029/2007JD009025, 2008 b.

Gaudel, A., Clark, H., Thouret, V., Jones, L., Inness, A., Flemming, J., Stein, O., Huijnen, V., Eskes, H., Nédélec, P., and Boulanger, D.: On the use of MOZAIC-IAGOS data to assess the ability of the MACC reanalysis to reproduce the distribution of ozone and CO in the UTLS over Europe, Tellus B, 67, 27955, doi:10.3402/tellusb.v67.27955, 2015.

Geer, A. J., Lahoz, W. A., Bekki, S., Bormann, N., Errera, Q., Eskes, H. J., Fonteyn, D., Jackson, D. R., Juckes, M. N., Massart, S., Peuch, V.-H., Rharmili, S., and Segers, A.: The ASSET intercomparison of ozone analyses: method and first results, Atmos. Chem. Phys., 6, 5445-5474, doi:10.5194/acp-6-5445-2006, 2006.
Hanson, D. and Mauersberger, K.: Laboratory studies of the nitric acid trihydrate: Implications for the south polar stratosphere, Geophys. Res. Lett., 15, 855-858, doi:10.1029/GL015i008p00855, 1988.

Hanson, D. R. and Ravishankara, A. R.: Reactive Uptake of $\mathrm{ClONO}_{2}$ onto Sulfuric Acid Due to Reaction with $\mathrm{HCl}$ and $\mathrm{H}_{2} \mathrm{O}$, J. Phys. Chem., 98, 5728-5735, doi:10.1021/j100073a026, 1994.

Hassler, B., Petropavlovskikh, I., Staehelin, J., August, T., Bhartia, P. K., Clerbaux, C., Degenstein, D., Mazière, M. D., Dinelli, B. M., Dudhia, A., Dufour, G., Frith, S. M., Froidevaux, L., GodinBeekmann, S., Granville, J., Harris, N. R. P., Hoppel, K., Hubert, D., Kasai, Y., Kurylo, M. J., Kyrölä, E., Lambert, J.-C., Levelt, P. F., McElroy, C. T., McPeters, R. D., Munro, R., Nakajima, H., Parrish, A., Raspollini, P., Remsberg, E. E., Rosenlof, K. H., Rozanov, A., Sano, T., Sasano, Y., Shiotani, M., Smit, H. G. J., Stiller, G., Tamminen, J., Tarasick, D. W., Urban, J., van der A, R. J., Veefkind, J. P., Vigouroux, C., von Clarmann, T., von Savigny, C., Walker, K. A., Weber, M., Wild, J., and Zawodny, J. M.: Past changes in the vertical distribution of ozone - Part 1: Measurement techniques, uncertainties and availability, Atmos. Meas. Tech., 7, 1395-1427, doi:10.5194/amt-7-1395-2014, 2014.

Hitchman, M. H., McKay, M., and Trepte, C. R.: A climatology of stratospheric aerosol, J. Geophys. Res., 99, 20689-20700, doi:10.1029/94JD01525, 1994.

Hollingsworth, A., Engelen, R. J., Textor, C., Benedetti, A., Boucher, O., Chevallier, F., Dethof, A., Elbern, H., Eskes, H., Flemming, J., Granier, C., Kaiser, J. W., Morcrette, J.J., Rayner, P., Peuch, V. H., Rouil, L., Schultz, M. G., Simmons, A. J., and The GEMS Consortium: Toward a Monitoring and Forecasting System For Atmospheric Composition: The GEMS Project, B. Am. Meteorol. Soc., 89, 1147-1164, doi:10.1175/2008BAMS2355.1, 2008

Huijnen, V., Williams, J., van Weele, M., van Noije, T., Krol, M., Dentener, F., Segers, A., Houweling, S., Peters, W., de Laat, J., Boersma, F., Bergamaschi, P., van Velthoven, P., Le Sager, P., Eskes, H., Alkemade, F., Scheele, R., Nédélec, P., and Pätz, H.-W.: The global chemistry transport model TM5: description and evaluation of the tropospheric chemistry version 3.0, Geosci. Model Dev., 3, 445-473, doi:10.5194/gmd-3-445-2010, 2010.

Huijnen, V., Williams, J. E., and Flemming, J.: Modeling global impacts of heterogeneous loss of $\mathrm{HO}_{2}$ on cloud droplets, ice particles and aerosols, Atmos. Chem. Phys. Discuss., 14, 8575-8632, doi:10.5194/acpd-14-8575-2014, 2014.

Im, U., Bianconi, R., Solazzo, E., Kioutsioukis, I., Badia, A., Balzarini, A., Baro, R., Bellasio, R., Brunner, D., Chemel, C., Curci, G., Flemming, J., Forkel, R., Giordano, L., JimenezGuerrero, P., Hirtl, M., Hodzic, A., Honzak, L., Jorba, O., Knote, C., Kuenen, J. J. P., Makar, P. A., Manders-Groot, A., Neal, L., Perez, J. L., Pirovano, G., Pouliot, G., San Jose, R., Savage, N., Schröder, W., Sokhi, R. S., Syrakov, D., Torian, A., Tuccella, P., Werhahn, K., Wolke, R., Yahya, K., Žabkar, R., Zhang, Y., Zhang, J., Hogrefe, C., and Galmarini, S.: Evaluation of operational online-coupled regional air quality models over Europe and North America in the context of AQMEII phase2. Part I: ozone, Atmos. Environ., 115, 404-420, doi:10.1016/j.atmosenv.2014.09.042, 2015.

Inness, A., Blechschmidt, A.-M., Bouarar, I., Chabrillat, S., Crepulja, M., Engelen, R. J., Eskes, H., Flemming, J., Gaudel, 
A., Hendrick, F., Huijnen, V., Jones, L., Kapsomenakis, J., Katragkou, E., Keppens, A., Langerock, B., de Mazière, M., Melas, D., Parrington, M., Peuch, V. H., Razinger, M., Richter, A., Schultz, M. G., Suttie, M., Thouret, V., Vrekoussis, M., Wagner, A., and Zerefos, C.: Data assimilation of satelliteretrieved ozone, carbon monoxide and nitrogen dioxide with ECMWF's Composition-IFS, Atmos. Chem. Phys., 15, 52755303, doi:10.5194/acp-15-5275-2015, 2015.

Jablonowski, C. and Williamson, D. L.: The pros and cons of diffusion, filters and fixers in atmospheric general circulation models, in: Numerical Techniques for Global Atmospheric Models, 381493, Springer, Berlin Heidelberg, doi:10.1007/978-3-642-116407, 2011.

Jöckel, P., Kerkweg, A., Pozzer, A., Sander, R., Tost, H., Riede, H., Baumgaertner, A., Gromov, S., and Kern, B.: Development cycle 2 of the Modular Earth Submodel System (MESSy2), Geosci. Model Dev., 3, 717-752, doi:10.5194/gmd-3-717-2010, 2010.

Lahoz, W. A., Errera, Q., Viscardy, S., and Manney, G. L.: The 2009 stratospheric major warming described from synergistic use of BASCOE water vapour analyses and MLS observations, Atmos. Chem. Phys., 11, 4689-4703, doi:10.5194/acp-11-46892011, 2011.

Lefever, K., van der A, R., Baier, F., Christophe, Y., Errera, Q., Eskes, H., Flemming, J., Inness, A., Jones, L., Lambert, J.C., Langerock, B., Schultz, M. G., Stein, O., Wagner, A., and Chabrillat, S.: Copernicus stratospheric ozone service, 20092012: validation, system intercomparison and roles of input data sets, Atmos. Chem. Phys., 15, 2269-2293, doi:10.5194/acp-152269-2015, 2015.

Lin, S.-J. and Rood, R. B.: Multidimensional flux-form semiLagrangian transport schemes, Mon. Weather Rev., 124, 20462070, 1996.

Livesey, N. J., Read, W. G., Froidevaux, L., Lambert, A., Manney, G. L., Pumphrey, H. C., Santee, M. L., Schwartz, M. J., Wang, S., Cofield, R. E., Cuddy, D. T., Fuller, R. A., Jarnot, R. F., Jiang, J. H., Knosp, B. W., Stek, P. C., Wagner, P. A., and Wu, D. L.: Earth Observing System (EOS) Aura Microwave Limb Sounder (MLS) Version 3.3 Level 2 data quality and description document, Tech. Rep. D-33509, JPL, 2011.

Madronich, S. and Flocke, S.: The Role of Solar Radiation in Atmospheric Chemistry, in: Environmental Photochemistry, edited by: Boule, P., Vol. 2/2L of The Handbook of Environmental Chemistry, 1-26, Springer Berlin Heidelberg, doi:10.1007/978-3-54069044-3_1, 1999.

Manney, G. L., Lawrence, Z. D., Santee, M. L., Livesey, N. J., Lambert, A., and Pitts, M. C.: Polar processing in a split vortex: Arctic ozone loss in early winter 2012/2013, Atmos. Chem. Phys., 15, 5381-5403, doi:10.5194/acp-15-5381-2015, 2015.

Marécal, V., Peuch, V.-H., Andersson, C., Andersson, S., Arteta, J., Beekmann, M., Benedictow, A., Bergström, R., Bessagnet, B., Cansado, A., Chéroux, F., Colette, A., Coman, A., Curier, R. L., Denier van der Gon, H. A. C., Drouin, A., Elbern, H., Emili, E., Engelen, R. J., Eskes, H. J., Foret, G., Friese, E., Gauss, M., Giannaros, C., Guth, J., Joly, M., Jaumouillé, E., Josse, B., Kadygrov, N., Kaiser, J. W., Krajsek, K., Kuenen, J., Kumar, U., Liora, N., Lopez, E., Malherbe, L., Martinez, I., Melas, D., Meleux, F., Menut, L., Moinat, P., Morales, T., Parmentier, J., Piacentini, A., Plu, M., Poupkou, A., Queguiner, S., Robertson, L., Rouïl, L., Schaap, M., Segers, A., Sofiev, M., Tarasson, L., Thomas,
M., Timmermans, R., Valdebenito, Á., van Velthoven, P., van Versendaal, R., Vira, J., and Ung, A.: A regional air quality forecasting system over Europe: the MACC-II daily ensemble production, Geosci. Model Dev., 8, 2777-2813, doi:10.5194/gmd8-2777-2015, 2015.

Maycock, A. C., Keeley, S. P. E., Charlton-Perez, A. J., and DoblasReyes, F. J.: Stratospheric circulation in seasonal forecasting models: implications for seasonal prediction, Clim. Dynam., 36, 309-321, doi:10.1007/s00382-009-0665-x, 2011.

Monge-Sanz, B. M., Chipperfield, M. P., Untch, A., Morcrette, J.J., Rap, A., and Simmons, A. J.: On the uses of a new linear scheme for stratospheric methane in global models: water source, transport tracer and radiative forcing, Atmos. Chem. Phys., 13, 9641-9660, doi:10.5194/acp-13-9641-2013, 2013.

Morcrette, J.-J., Boucher, O., Jones, L., Salmond, D., Bechtold, P., Beljaars, A., Benedetti, A., Bonet, A., Kaiser, J. W., Razinger, M., Schulz, M., Serrar, S., Simmons, A. J., Sofiev, M., Suttie, M., Tompkins, A. M., and Untch, A.: Aerosol analysis and forecast in the European Centre for Medium-RangeWeather Forecasts Integrated Forecast System: Forward modeling, J. Geophys. Res., 114, D06206, doi:10.1029/2008JD011235, 2009.

Muncaster, R., Bourqui, M. S., Chabrillat, S., Viscardy, S., Melo, S. M. L., and Charbonneau, P.: A simple framework for modelling the photochemical response to solar spectral irradiance variability in the stratosphere, Atmos. Chem. Phys., 12, 77077724, doi:10.5194/acp-12-7707-2012, 2012.

Murphy, D. M. and Koop, T.: Review of the vapour pressures of ice and supercooled water for atmospheric applications, Q. J. Roy. Meteor. Soc., 131, 1539-1565, doi:10.1256/qj.04.94, 2005.

Pausata, F. S. R., Pozzoli, L., Vignati, E., and Dentener, F. J.: North Atlantic Oscillation and tropospheric ozone variability in Europe: model analysis and measurements intercomparison, Atmos. Chem. Phys., 12, 6357-6376, doi:10.5194/acp-12-63572012, 2012.

Platt, U. and Stutz, J.: Differential Optical Absorption Spectroscopy, Physics of Earth and Space Environments, Berlin: Springer, available at: http://www.springerlink.com/content/ 978-3-540-21193-8 (last access: February 2016), 2008.

Qu, Z., Gschwind, B., Lefevre, M., and Wald, L.: Improving HelioClim-3 estimates of surface solar irradiance using the McClear clear-sky model and recent advances in atmosphere composition, Atmos. Meas. Tech., 7, 3927-3933, doi:10.5194/amt-73927-2014, 2014.

Read, W. G., Lambert, A., Bacmeister, J., Cofield, R. E., Christensen, L. E., Cuddy, D. T., Daffer, W. H., Drouin, B. J., Fetzer, E., Froidevaux, L., Fuller, R., Herman, R., Jarnot, R. F., Jiang, J. H., Jiang, Y. B., Kelly, K., Knosp, B. W., Kovalenko, L. J., Livesey, N. J., Liu, H.-C., Manney, G. L., Pickett, H. M., Pumphrey, H. C., Rosenlof, K. H., Sabounchi, X., Santee, M. L., Schwartz, M. J., Snyder, W. V., Stek, P. C., Su, H., Takacs, L. L., Thurstans, R. P., Vömel, H., Wagner, P. A., Waters, J. W., Webster, C. R., Weinstock, E. M., and Wu, D. L.: Aura Microwave Limb Sounder upper tropospheric and lower stratospheric $\mathrm{H}_{2} \mathrm{O}$ and relative humidity with respect to ice validation, J. Geophys. Res.-Atmos., 112, D24S35, doi:10.1029/2007JD008752, 2007.

Robichaud, A., Ménard, R., Chabrillat, S., de Grandpré, J., Rochon, Y. J., Yang, Y., and Charette, C.: Impact of energetic particle precipitation on stratospheric polar constituents: an assessment using monitoring and assimilation of operational MIPAS data, 
Atmos. Chem. Phys., 10, 1739-1757, doi:10.5194/acp-10-17392010, 2010.

Raspollini, P., Carli, B., Carlotti, M., Ceccherini, S., Dehn, A., Dinelli, B. M., Dudhia, A., Flaud, J.-M., López-Puertas, M., Niro, F., Remedios, J. J., Ridolfi, M., Sembhi, H., Sgheri, L., and von Clarmann, T.: Ten years of MIPAS measurements with ESA Level 2 processor V6 - Part 1: Retrieval algorithm and diagnostics of the products, Atmos. Meas. Tech., 6, 2419-2439, doi:10.5194/amt-6-2419-2013, 2013.

Richter, A., Burrows, J. P., Nüß, H., Granier, C., and Niemeier, U.: Increase in tropospheric nitrogen dioxide over China observed from space, Nature, 437, 129-132, doi:10.1038/nature04092, 2005.

Sander, S., Friedl, R., DeMore, W., Ravishankara, A.,Golden, D., Kolb, C., Kurylo, M., Hampson, R., Huie, R., Molina, M., and Moortgat, G.: Chemical Kinetics and Photochemical Data for Use in Stratospheric Modeling. Supplement to Evaluation 12: Update of Key Reactions. Evaluation Number 13, JPL Publication 00-3, Jet Propulsion Laboratory, Pasadena, available at: http: //jpldataeval.jpl.nasa.gov (last access: 31 August 2016), 2000.

Sander, S., Friedl, R., Golden, D., Kurylo, M., Moortgat, G., KellerRudek, H., Wine, P., Ravishankara, A., Kolb, C., Molina, M., Finlayson-Pitts, B., Huie, R., and Orkin, V.: Chemical Kinetics and Photochemical Data for Use in Atmospheric Studies. Evaluation Number 15, JPL Publication 06-2, Jet Propulsion Laboratory, Pasadena, available at: http://jpldataeval.jpl.nasa.gov (last access: 31 August 2016), 2006.

Sander, S. P., Abbatt, J. R., Burkholder, J. B., Friedl, R. R., Golden, D. M., Huie, R. E., Kolb, C. E., Kurylo, G., Moortgat, K., Orkin, V. L., and Wine, P. H.: Chemical kinetics and Photochemical Data for Use in Atmospheric studies, Evaluation Number 17, JPL Publication 10-6, Jet Propulsion Laboratory, Pasadena, 2011.

Sandu, A. and Sander, R.: Technical note: Simulating chemical systems in Fortran90 and Matlab with the Kinetic PreProcessor KPP-2.1, Atmos. Chem. Phys., 6, 187-195, doi:10.5194/acp-6187-2006, 2006.

Santee, M. L., Lambert, A., Read, W. G., Livesey, N. J., Manney, G. L., Cofeld, R. E., Cuddy, D. T., Daffer, W. H., Drouin, B. J., Froidevaux, L., Fuller, R. A., Jarnot, R. F., Knosp, B. W., Perun, V. S., Snyder, W. V., Stek, P. C., Thurstans, R. P., Wagner, P. A., Waters, J. W., Connor, B., Urban, J., Murtagh, D., Ricaud, P., Barret, B., Kleinboehl, A., Kuttippurath, J., Kuellmann, H., von Hobe, M., Toon, G. C., and Stachnik, R. A.: Validation of the Aura Microwave Limb Sounder ClO measurements, J. Geophys. Res., 113, D15S22, doi:10.1029/2007JD008762, 2008.

Scaife, A., Spangehl, T., Fereday, D., Cubasch, U., Langematz, U., Akiyoshi, H., Bekki, S., Braesicke, P., Butchart, N., Chipperfield, M., Gettelman, A., Hardiman, S., Rozanov, M. M. E., and Shepherd, T.: Climate change projections and stratosphere-troposphere interaction, Clim. Dynam., 38, 20892097, doi:10.1007/s00382-011-1080-7, 2012.

Shepherd, T. G.: Transport in the Middle Atmosphere, J. Meteorol. Soc. Jpn., 85B, 165-191, doi:10.2151/jmsj.85B.165, 2007.

Solomon, S., Rosenlof, K. H., Portmann, R. W., Daniel, J. S., Davis, S. M., Sanford, T. J., and Plattner, G.-K.: Contributions of stratospheric water vapor to decadal changes in the rate of global warming, Science, 327, 1219-1223, doi:10.1126/science.1182488, 2010.
Stevenson, D. S., Dentener, F. J., Schultz, M. G., Ellingsen, K., van Noije, T. P. C., Wild, O., Zeng, G., Amann, M., Atherton, C. S., Bell, N., Bergmann, D. J., Bey, I., Butler, T., Cofala, J., Collins, W. J., Derwent, R. G., Doherty, R. M., Drevet, J., Eskes, H. J., Fiore, A. M., Gauss, M., Hauglustaine, D. A., Horowitz, L. W., Isaksen, I. S. A., Krol, M. C., Lamarque, J.-F., Lawrence, M. G., Montanaro, V., Müller, J.-F., Pitari, G., Prather, M. J., Pyle, J. A., Rast, S., Rodriguez, J. M., Sanderson, M. G., Savage, N. H., Shindell, D. T., Strahan, S. E., Sudo, K., and Szopa, S.: Multimodel ensemble simulations of present-day and near-future tropospheric ozone, J. Geophys. Res., 111, D08301, doi:10.1029/2005JD006338, 2006.

Strong, K., Wolff, M. A., Kerzenmacher, T. E., Walker, K. A., Bernath, P. F., Blumenstock, T., Boone, C., Catoire, V., Coffey, M., De Mazière, M., Demoulin, P., Duchatelet, P., Dupuy, E., Hannigan, J., Höpfner, M., Glatthor, N., Griffith, D. W. T., Jin, J. J., Jones, N., Jucks, K., Kuellmann, H., Kuttippurath, J., Lambert, A., Mahieu, E., McConnell, J. C., Mellqvist, J., Mikuteit, S., Murtagh, D. P., Notholt, J., Piccolo, C., Raspollini, P., Ridolfi, M., Robert, C., Schneider, M., Schrems, O., Semeniuk, K., Senten, C., Stiller, G. P., Strandberg, A., Taylor, J., Tétard, C., Toohey, M., Urban, J., Warneke, T., and Wood, S.: Validation of ACE-FTS $\mathrm{N}_{2} \mathrm{O}$ measurements, Atmos. Chem. Phys., 8, 47594786, doi:10.5194/acp-8-4759-2008, 2008.

SPARC CCMVal: Report on the Evaluation of Chemistry-Climate Models, edited by: Eyring, V., Shepherd, T. G., and Waugh, D. W., SPARC Report No. 5, WCRP-X, WMO/TD-No. X, available at: http://www.sparc-climate.org/publications/ (last access: 31 August 2016), 2010.

Talagrand, O. and Courtier, P.: Variational assimilation of meteorological observations with the adjoint vorticity equation, I, Theory, Q. J. Roy. Meteor. Soc., 23, 1311-1328, doi:10.1002/qj.49711347812, 1987.

Theys, N., Van Roozendael, M., Errera, Q., Hendrick, F., Daerden, F., Chabrillat, S., Dorf, M., Pfeilsticker, K., Rozanov, A., Lotz, W., Burrows, J. P., Lambert, J.-C., Goutail, F., Roscoe, H. K., and De Mazière, M.: A global stratospheric bromine monoxide climatology based on the BASCOE chemical transport model, Atmos. Chem. Phys., 9, 831-848, doi:10.5194/acp-9-831-2009, 2009.

Thornton, H. E., Jackson, D. R., Bekki, S., Bormann, N., Errera, Q., Geer, A. J., Lahoz, W. A., and Rharmili, S.: The ASSET intercomparison of stratosphere and lower mesosphere humidity analyses, Atmos. Chem. Phys., 9, 995-1016, doi:10.5194/acp-9995-2009, 2009.

Thuburn, J. and Craig, G.: GCM tests of theories for the height of the tropopause, J. Atmos. Sci., 54, 869-882, doi:10.1175/15200469(1997)054<0869:GTOTFT>2.0.CO;2, 1997.

van der A, R. J., Allaart, M. A. F., and Eskes, H. J.: Extended and refined multi sensor reanalysis of total ozone for the period 19702012, Atmos. Meas. Tech., 8, 3021-3035, doi:10.5194/amt-83021-2015, 2015.

Viscardy, S., Errera, Q., Christophe, Y., Chabrillat, S., and Lambert, J.-C.: Evaluation of Ozone Analyses From UARS MLS Assimilation by BASCOE Between 1992 and 1997, IEEE J-STARS, 3, 190-202, doi:10.1109/JSTARS.2010.2040463, 2010.

von Glasow, R. and Crutzen, P. J.: Tropospheric halogen chemistry, in: The Atmosphere, edited by: Keeling, R. F., Vol. 4 Treatise 
on Geochemistry, edited by: Holland, H. D. and Turekian, K. K., Elsevier-Pergamon, Oxford, 2007.

Wang, D. Y., Höpfner, M., Blom, C. E., Ward, W. E., Fischer, H., Blumenstock, T., Hase, F., Keim, C., Liu, G. Y., Mikuteit, S., Oelhaf, H., Wetzel, G., Cortesi, U., Mencaraglia, F., Bianchini, G., Redaelli, G., Pirre, M., Catoire, V., Huret, N., Vigouroux, C., De Mazière, M., Mahieu, E., Demoulin, P., Wood, S., Smale, D., Jones, N., Nakajima, H., Sugita, T., Urban, J., Murtagh, D., Boone, C. D., Bernath, P. F., Walker, K. A., Kuttippurath, J., Kleinböhl, A., Toon, G., and Piccolo, C.: Validation of MIPAS HNO3 operational data, Atmos. Chem. Phys., 7, 4905-4934, doi:10.5194/acp-7-4905-2007, 2007.

Wetzel, G., Bracher, A., Funke, B., Goutail, F., Hendrick, F., Lambert, J.-C., Mikuteit, S., Piccolo, C., Pirre, M., Bazureau, A., Belotti, C., Blumenstock, T., De Mazière, M., Fischer, H., Huret, N., Ionov, D., López-Puertas, M., Maucher, G., Oelhaf, H., Pommereau, J.-P., Ruhnke, R., Sinnhuber, M., Stiller, G., Van Roozendael, M., and Zhang, G.: Validation of MIPASENVISAT $\mathrm{NO}_{2}$ operational data, Atmos. Chem. Phys., 7, 32613284, doi:10.5194/acp-7-3261-2007, 2007.
Williams, J. E., Strunk, A., Huijnen, V., and van Weele, M.: The application of the Modified Band Approach for the calculation of on-line photodissociation rate constants in TM5: implications for oxidative capacity, Geosci. Model Dev., 5, 15-35, doi:10.5194/gmd-5-15-2012, 2012.

Williams, J. E., van Velthoven, P. F. J., and Brenninkmeijer, C. A. M.: Quantifying the uncertainty in simulating global tropospheric composition due to the variability in global emission estimates of Biogenic Volatile Organic Compounds, Atmos. Chem. Phys., 13, 2857-2891, doi:10.5194/acp-13-2857-2013, 2013.

World Meteorological Organization (WMO): Meteorology A Three-Dimensional Science: Second Session of the Commission for Aerology, WMO Bulletin IV(4), WMO, Geneva, 134-138, 1957.

Yarwood, G., Rao, S., Yocke, M., and Whitten, G.: Updates to the carbon bond chemical mechanism: CB05, Final report to the US EPA, EPA Report Number: RT-0400675, available at: http://www.camx.com (last access: 16 July 2015), 2005. 